University of Nebraska - Lincoln

DigitalCommons@University of Nebraska - Lincoln

$11-2014$

\title{
Spatiotemporal variation in flow-dependent recruitment of long- lived riverine fish: Model development and evaluation
}

\author{
Daisuke Goto \\ University of Nebraska-Lincoln, daisukegoto@att.net \\ Martin J. Hamel \\ University of Nebraska-Lincoln, mhamel2@unl.edu \\ Jeremy J. Hammen \\ Nebraska Department of Environmental Quality, Jeremy_hammen@fws.gov \\ Mathew L. Rugg \\ University of Nebraska-Lincoln, mrugg@mt.gov \\ Mark A. Pegg \\ University of Nebraska-Lincoln, mpegg2@unl.edu
}

See next page for additional authors

Follow this and additional works at: https://digitalcommons.unl.edu/bioscifacpub

Part of the Aquaculture and Fisheries Commons, Bioinformatics Commons, Population Biology

Commons, and the Terrestrial and Aquatic Ecology Commons

Goto, Daisuke; Hamel, Martin J.; Hammen, Jeremy J.; Rugg, Mathew L.; Pegg, Mark A.; and Forbes, Valery E., "Spatiotemporal variation in flow-dependent recruitment of long-lived riverine fish: Model development and evaluation" (2014). Faculty Publications in the Biological Sciences. 369.

https://digitalcommons.unl.edu/bioscifacpub/369

This Article is brought to you for free and open access by the Papers in the Biological Sciences at DigitalCommons@University of Nebraska - Lincoln. It has been accepted for inclusion in Faculty Publications in the Biological Sciences by an authorized administrator of DigitalCommons@University of Nebraska - Lincoln. 


\section{Authors}

Daisuke Goto, Martin J. Hamel, Jeremy J. Hammen, Mathew L. Rugg, Mark A. Pegg, and Valery E. Forbes 


\title{
Spatiotemporal variation in flow-dependent recruitment of long-lived riverine fish: Model development and evaluation
}

\author{
Daisuke Goto, ${ }^{1}$ Martin J. Hamel, ${ }^{2}$ Jeremy J. Hammen, ${ }^{2,3}$ \\ Matthew L. Rugg, ${ }^{2}$ Mark A. Pegg, ${ }^{2}$ and Valery E. Forbes ${ }^{1}$ \\ 1. School of Biological Sciences, University of Nebraska-Lincoln, 348 Manter Hall, Lincoln, NE 68588-0118, USA \\ 2. School of Natural Resources, University of Nebraska-Lincoln, Hardin Hall, 3310 Holdrege Street, Lincoln, NE 68583-0973, USA \\ 3. Surface Water Unit - Water Division, Nebraska Department of Environmental Quality, \\ 1200 N Street, The Atrium, Suite 400, Lincoln, NE 68509-8922, USA \\ Corresponding author - Daisuke Goto, email daisukegoto@att.net
}

\begin{abstract}
Natural flow regimes can play a major role as an overarching ecosystem driver in reproduction and recruitment of riverine fishes. Human needs for freshwater however have altered hydrology of many riverine systems worldwide, threatening fish population sustainability. To understand and predict how spatiotemporal dynamics of flow regimes influence reproductive and recruitment variability, and ultimately population sustainability of shovelnose sturgeon (Scaphirhynchus platorynchus), we develop a spatially explicit (1D) individual-based population model that mechanistically (via energetics-based processes) simulates daily activities (dispersal, spawning, foraging, growth, and survival). With field observations of sturgeon and habitat conditions in a major tributary of the Missouri River system (USA), we calibrate and evaluate the model via pattern-oriented modeling. Model simulation experiments using 17-year environmental time series data showed that seasonal and interannual variation in hydrological conditions plays a major role in timing, location, and magnitude of spawning and recruitment success of sturgeon. During droughts, consecutive weak yearclasses resulted in a steady population decline. While low flow and subsequent low prey production limited foraging opportunities and slowed gonad development, these conditions were not severe enough for adults to abort the reproductive cycle. Post-settlement larval sturgeon were however unable to feed efficiently to grow out of a size-dependent 'predation window', resulting in high mortality. Slow growth and low survival of larval sturgeon thus likely play a larger role in recruitment failures during droughts than low or lack of spawning events.
\end{abstract}

Keywords: River, Population dynamics, Energetics, Individual-based models, Spatially explicit models, Shovelnose sturgeon, Conservation

\section{Introduction}

Life history strategies of organisms have evolved by adaptation to the natural variability of environmental drivers (Hutchings, 2002; Lytle and Poff, 2004; Winemiller and Rose, 1992). Consistent availability of natural habitats suitable for reproduction and recruitment is therefore essential in maintaining sustainable populations (Gibson, 1994). A variety of human activities have however facilitated habitat degradation and destruction, threatening population sustainability of many species in aquatic and terrestrial systems (Lucas and Marmulla, 2000). Understanding underlying mechanisms driving environment-life history trait relationships for populations under environmental stress is thus becoming increasingly important for conservation and management in these systems (Hampe and Petit, 2005).
In riverine systems, the natural flow regime can play a critical role in reproduction and recruitment of aquatic and terrestrial organisms (Humphries et al., 1999; Nunn et al., 2007), and ultimately in structuring community assemblages and functioning as an overarching ecosystem driver (Bunn and Arthington, 2002; Lytle and Poff, 2004). Human needs for freshwater however have made substantial impacts on hydrology and geomorphology of many riverine systems worldwide (Nilsson and Berggren, 2000). Many of these systems have been channelized to regulate the flow; regulated systems usually have less capacity to buffer perturbations (e.g., droughts) than natural systems (Palmer et al., 2008). Flow regulation for instance has altered life-history traits of fish species, resulting in persistent recruitment failures and threatening sustainability of populations in these systems (Bunn and Arthington, 2002; Poff et al., 1997). 
Recruitment variability in fish is often regulated by environmental drivers (e.g., water temperature) that affect growth and survival during early life stages (Anderson, 1988; Houde, 1987; Houde, 2009). Cyclic prey population dynamics linked with environmental variability during the transition to the feeding stage ('critical period') has been hypothesized as a dominant driver of recruitment success (Cushing, 1996; Humphries et al., 2013); specifically, survival of larval fish may depend on fast growth via consistent foraging success to avoid size-dependent predation (Houde, 2009).

While a number of studies have examined the roles of biological and environmental drivers in foraging success and ultimately recruitment in marine systems (Boehlert and Mundy, 1988), underlying mechanisms of recruitment success for riverine fishes (i.e., flow-recruitment relationships) is less understood (Bunn and Arthington, 2002; Lytle and Poff, 2004). For riverine fishes, flow regime changes in spawning and rearing grounds may bring about changes in temperature regime and food availability that could disrupt early life stage processes such as timing and location of spawning and settlement (Humphries et al., 1999; King et al., 2003; Nunn et al., 2007).

River flow may also indirectly influence recruitment success via energetics and maturation processes in juvenile and adult females that ultimately determine reproductive output (Encina and Granado-Lorencio, 1997). Variation in energy intake among individuals and species can result in a range of energy investment strategies for reproduction (McBride et al., 2013). For instance, floods and droughts can reduce foraging efficiency of drift-feeding fishes, subsequently reducing energy availability for growth and gonad development (Collins and Anderson, 1999; Encina and Granado-Lorencio, 1997). Large fluctuations in flow regimes during extreme hydrologic events can thus lead to delayed maturation and skipped spawning for riverine fishes (Jonsson et al., 2013). While environmental variation may be a strong driver of recruitment, intrinsic drivers such as energy allocation in females may also be equally important in regulating reproductive success.

Here we develop and evaluate a simulation model that assesses ecological impacts of altered flow regimes on Scaphirhynchus sturgeon reproductive and recruitment success, and consequences for population sustainability in a regulated river. We use a spatially explicit individual-based population model that explicitly and implicitly simulates individual-level daily activities in response to varying flow regimes (e.g., flowdependent dispersal, spawning, foraging, and mortality, Figure 1 and Appendix A in Supplementary material) during the entire life cycle. Further, this model is designed to synthesize currently available information on Scaphirhynchus life history (Wildhaber et al., 2007; Wildhaber et al., 2011). Model simulations should shed light on this critical link by examining population-level responses to hydrologic variation that emerge from a variety of individual-level traits. Specifically, we explicitly test the role of energetics as an underlying mechanism of how varying flow regimes drive (1) reproductive ecology including spawning habitat selection and decision to spawn (e.g., spawning frequency and location), and (2) recruitment including settlement location and survival of larvae and juveniles, all of which would ultimately influence population sustainability of fishes in regulated rivers.

\section{Methods and materials}

\subsection{Study species}

Scaphirhynchus sturgeon, long-lived iteroparous species with infrequent spawning, rely on repeatability of natural environmental cues such as natural flow dynamics for timing and location of spawning events, and ultimately for recruitment success (DeLonay et al., 2009). Field observations suggest that these river flow-related cues appear to signal these sturgeon for habitat conditions (e.g., water temperature) suitable for spawning and rearing (DeLonay et al., 2009). Yet it is not clear how these observed responses in individual reproductive traits emerge as state dynamics of the populations (Jager, 2001). While recent concerted efforts have gained some insights into the reproductive physiology and behaviors of Scaphirhynchus sturgeon in response to altered environmental conditions (Korschgen, 2007), underlying mechanisms of reproduction and recruitment of these species are still poorly identified. There is thus an urgent need to understand the ecological and physiological traits involved in the reproductive and recruitment ecology of Scaphirhynchus spp. in regulated rivers to assist sturgeon conservation and river management (DeLonay et al., 2009).
Figure 1. Conceptual diagram of a spatially explicit individual-based model of shovelnose sturgeon $\left(\mathrm{SEIBM}-1 \mathrm{D}_{\mathrm{SNS}}\right)$. Boxes indicate life stages of shovelnose sturgeon in the model. Italicized texts indicate individual-level processes that facilitate the transition to the next life stage in the model. Diamond shapes indicate environmental drivers (inputs) of the individual-level processes in the model. Detailed description of how the environmental drivers influence each process of the model is provided in Appendix A (Supplementary material).

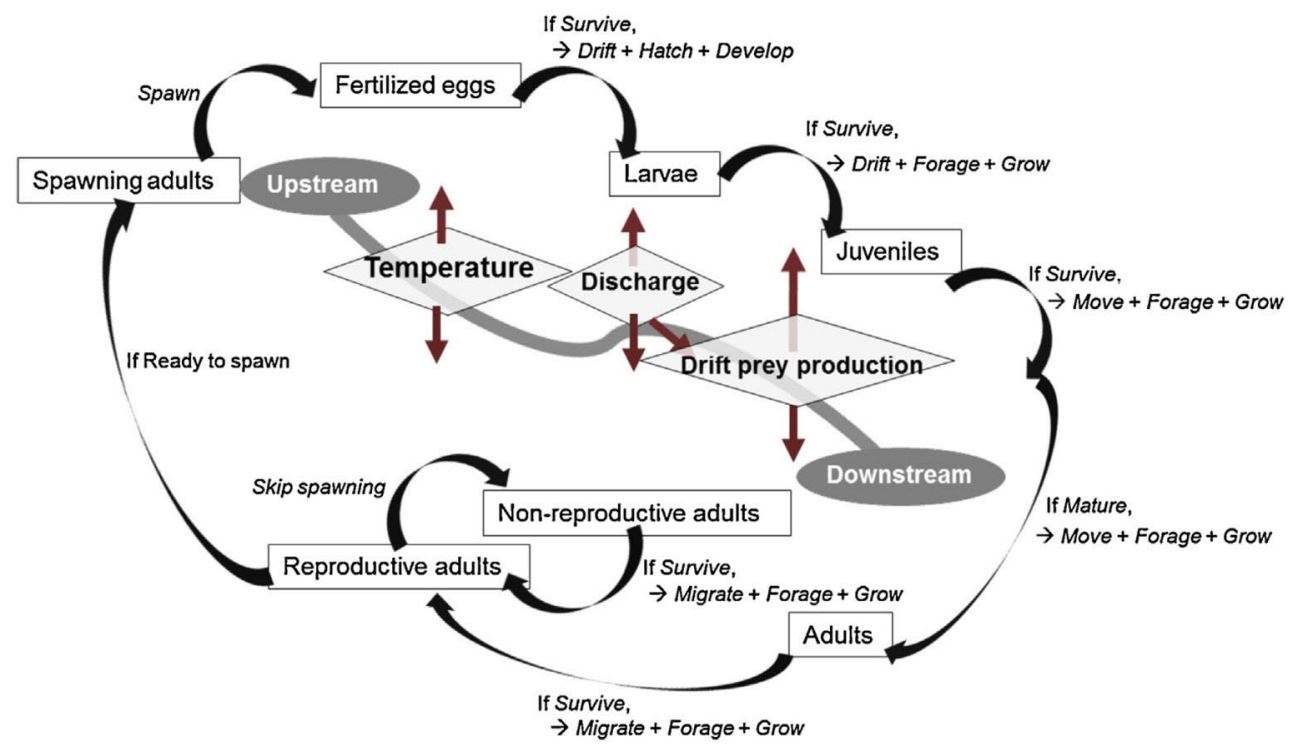




\subsection{Study system}

The sturgeon model was calibrated and evaluated for the lower Platte River (LPR, Nebraska, USA) population; the LPR is one of the major tributaries of the Missouri River, located between Plattsmouth and Columbus ( 162 river km or rkm), Nebraska (Figure 2), providing spawning and nursing habitats for fish and wildlife including endangered species such as pallid sturgeon (Scaphirhynchus albus) (DeLonay et al., 2009; Peters and Parham, 2008). Flow regimes of the Missouri River and many of its tributaries have been considerably altered from their natural conditions because of impoundments and channelization (Pegg et al., 2003; Reuter et al., 2009). In the LPR, its hydrology and channel geomorphology have been altered from natural conditions since the 1850s to meet a variety of human needs including hydroelectricity, flood control, agricultural land use, and irrigation in the region (Ginting et al., 2008).
Figure 2. Study system; (a) a map of the lower Platte River (LPR), Nebraska, USA; (b) observed spatially averaged daily mean discharge rate $\left(\mathrm{m} \mathrm{s}^{-1}\right)$ in the LPR during 1995-2011 (USGS National Water Information System, http:/ / waterdata.usgs.gov/nwis). Light pink rectangle indicates the drought period (2002-2006).
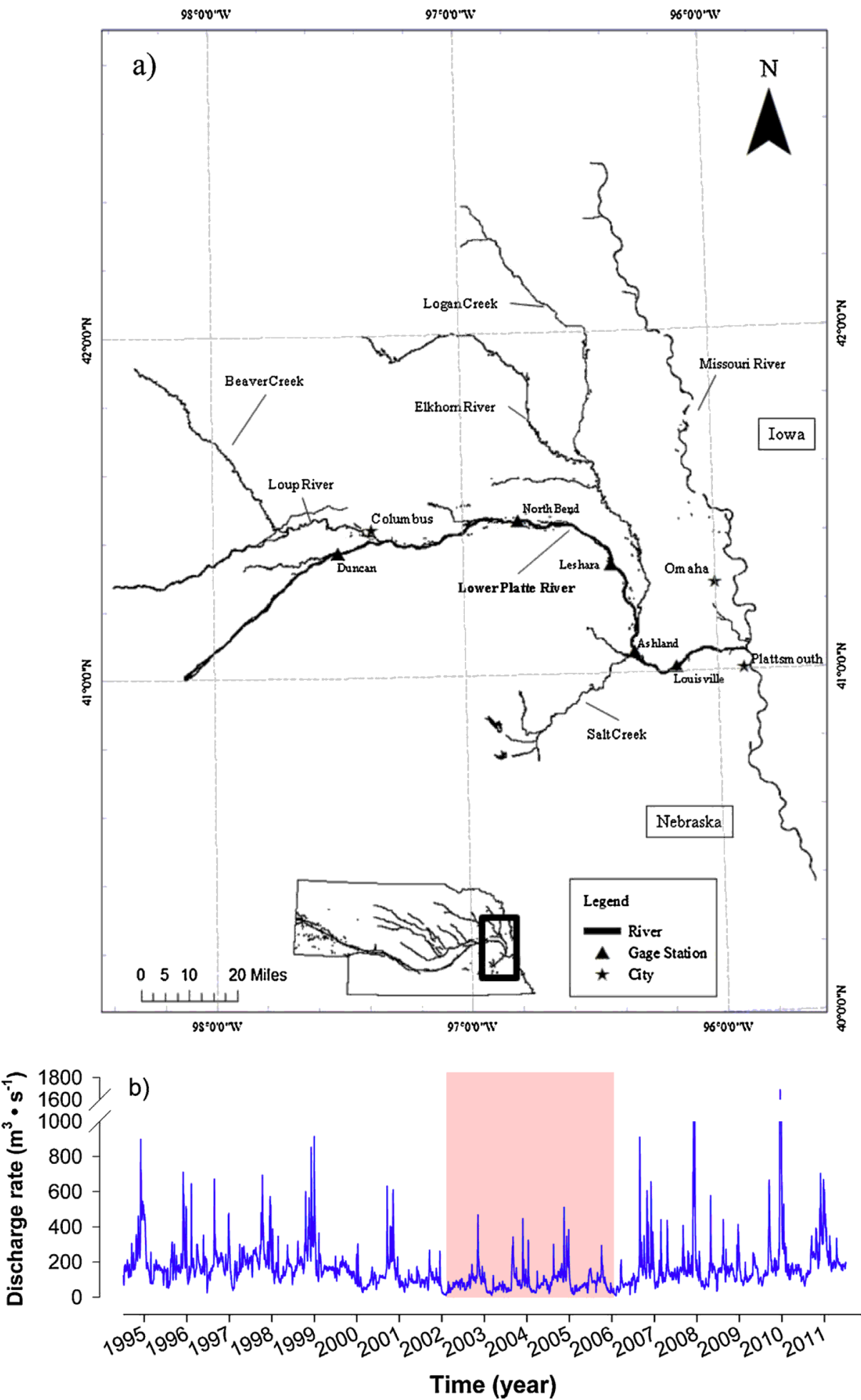


\subsection{Model description}

The following sections describe a spatially explicit (1-dimensional) individual-based model for shovelnose sturgeon (Scaphirhynchus platorynchus) (SEIBM-1D ${ }_{\text {SNS }}$ ) according to the Overview, Design concepts, and Details (ODD) protocol (Grimm et al., 2006; Grimm et al., 2010). The SEIBM-1D ${ }_{\text {SNS }}$ was coded in IDL version 8.2.1 (Exelis Visual Information Solutions, Inc., Colorado, USA).

\subsubsection{Overview}

2.3.1.1. Purpose. Our primary objectives were (1) to understand mechanisms underlying direct and indirect effects of altered flow regimes and channel morphology on recruitment variability and long-term population sustainability of Scaphirhynchus spp., and (2) to evaluate management implications in regulated rivers. We initially develop the model for shovelnose sturgeon because of habitat requirements similar to its endangered, sympatric species, pallid sturgeon, and relatively large field data availability for model parameterization and evaluation (DeLonay et al., 2009). The SEIBM-1D SNS $_{\text {. }}$ continuously runs to simulate sturgeon population dynamics in the LPR model environment over multiple years and generations.

2.3.1.2. Entities, state variables, and scales. The SEIBM- $1 D_{\text {SNS }}$ has two entities: (1) sturgeon and (2) the river environment. The model keeps track of state variables of the entire life cycle of sturgeon; early life stages (fertilized eggs, yolk-sac larvae, and post-settlement (swim-up) larvae, and age-0 juveniles) are represented as super-individuals ( $\mathrm{SI}_{\mathrm{YOY}}$, Scheffer et al., 1995), whereas age 1+ juveniles and adults are represented as individual fish. Each $\mathrm{SI}_{\text {YOY }}$ represents a collection of individuals ("cohorts") from the same mother. The sturgeon model has 12 state variables; total body length $(\mathrm{mm})$, total body mass $(\mathrm{g})$, storage mass $(\mathrm{g})$, structural mass $(\mathrm{g})$, gonadal mass $(\mathrm{g})$, the number of individuals each $\mathrm{SI}_{\mathrm{YOY}}$ represents, maturity status, reproductive status, physiological condition, sex, age (years), and longitudinal location in the river ( $\mathrm{rkm})$.

The model river environment (the LPR) has seven state variables; daily and depth averages of spatially explicit discharge $\left(\mathrm{m}^{3} \mathrm{~s}^{-1}\right)$, depth $(\mathrm{m})$, width of the wetted area $(\mathrm{m})$, turbidity (NTB), and drift invertebrate prey (Chironomidae, etc.) biomass $\left(\mathrm{g} \mathrm{m}^{-2}\right)$, and spatially uniform temperature $\left({ }^{\circ} \mathrm{C}\right)$ and photoperiod (h).

The spatial scale of the model is determined by the model LPR structure, which is equally divided into 162 longitudinal rectangular segments (or grid cells of $1.0 \mathrm{rkm}$ each). The model simulates the sturgeon population and updates state variables at discrete daily time steps.

2.3.1.3. Process overview and scheduling. On each simulation day, habitat conditions (temperature, turbidity, discharge, depth, width, and drift prey biomass) are first updated, and then the SEIBM-1D ${ }_{\mathrm{SNS}}$ evaluates actions by individual sturgeon (with submodels) in the following order: (1) spawning (adults in the reproductive cycle only), (2) hatching and larval development (eggs and yolk-sac larvae only), (3) movement, (4) foraging, (5) growth (via bioenergetics), and (6) mortality (Figure 1). State variables are updated at the end of each action. At the beginning of each simulation year, maturity is evaluated once, and mature individuals with 'good' physiological condition (see Growth submodel in Appendix A (Supplementary material) for the minimum threshold) enter the annual reproductive cycle. Spawning normally occurs from late spring to early summer only when relative gonad mass, photoperiod, discharge rate, and water temperature all meet the thresholds (see Spawning submodel in Appendix A (Supplementary material)) concurrently.

\subsubsection{Design concepts}

2.3.2.1. Basic principles. Our model is primarily based on energetics principles. There are existing complex, mechanistically rich IBMs that simulate effects of thermal and flow regimes on population dynamics of stream and riverine fishes (e.g., Frank and Baret, 2013; Piou and Prévost, 2012; Railsback et al., 2009). However, to explicitly evaluate the role of energetics in understanding how spatial and temporal environmental variability contributes to reproductive (e.g., spawning frequency) and recruitment (e.g., sources of larval mortality) variability, we decided to develop a new model that can capture the entire process of energy acquisition and allocation processes (e.g., flow-driven foraging and gonad maturation) of each individual fish (Figure 1).

2.3.2.2. Emergence. Demographic characteristics (e.g., abundance, age structure, and biomass) and spatial distribution of the sturgeon population in the river emerge from individual-level processes (e.g., individual growth, survival, reproduction, and movement) in response to habitat conditions and indirect competition with other individuals for prey (density dependence) within the population.

2.3.2.3. Adaptation. Individuals adjust movement and energy allocation (storage, structure, or gonad) in response to energy intake, physiological condition, maturity status, and environmental conditions. Further, an adult's decision to enter and complete a reproductive cycle (i.e., frequency of spawning) depends on its previous experiences with environmental conditions and physiological condition (see Growth submodel in Appendix A (Supplementary material) for details).

2.3.2.4. Sensing. We assume that sturgeon are able to sense gradients of environmental conditions (discharge and depth) and prey availability (drift invertebrate density) between neighboring grid cells when they make movement decisions.

2.3.2.5. Interaction. We assume that sturgeon indirectly interact with each other through density-dependent exploitative competition (see Foraging submodel in Appendix A (Supplementary material)) when they are located in the same cell.

2.3.2.6. Stochasticity. Initial age-specific length, the ability of fish to sense habitat conditions, prey availability (body size and biomass), prey capture success, spawning, and mortality are assumed to have a stochastic component to represent inherent uncertainty (e.g., sensing) and random processes (e.g., prey capture).

2.3.2.7. Observation. State variables and spatial locations of model individual sturgeon are recorded daily. These state variables are then used to compute spatial and temporal demographic characteristics (e.g., spawning biomass) of the population.

2.3.2.8. Input data. Model inputs include initial population characteristics (e.g., age structure and body size distribution) of sturgeon based on field surveys (Peters and Parham, 2008), empirical time series data of temperature and discharge in the LPR (Table 1 and Figure 2), turbidity, depth, and width data empirically derived from discharge-dependent functions (Appendix $C$ in Supplementary material), and simulated data of photoperiod (Appendix $C$ in Supplementary material) and drift prey production (Appendix A in Supplementary material). Derivation of environmental input data is described in Appendix C (Supplementary material). 
Table 1. Annual means of estimated daily water temperatures in lower Platte River (1995-2011).

\begin{tabular}{lllll}
\hline Time (year) & Annual mean & SD & Maximum & Minimum \\
\hline 1995 & 13.85 & 11.05 & 29.70 & 0.010 \\
1996 & 10.88 & 8.16 & 22.43 & 0.004 \\
1997 & 12.83 & 9.34 & 26.00 & 0.010 \\
1998 & 13.81 & 9.51 & 27.19 & 0.405 \\
1999 & 13.11 & 8.15 & 24.58 & 1.558 \\
2000 & 12.81 & 8.73 & 25.10 & 0.505 \\
2001 & 13.61 & 9.51 & 26.99 & 0.205 \\
2002 & 13.81 & 9.01 & 26.50 & 1.100 \\
2003 & 12.82 & 9.23 & 25.81 & 0.005 \\
2004 & 12.88 & 9.60 & 26.46 & 0.002 \\
2005 & 15.11 & 10.43 & 29.80 & 0.400 \\
2006 & 12.81 & 8.80 & 25.19 & 0.405 \\
2007 & 14.81 & 10.39 & 29.43 & 0.168 \\
2008 & 13.46 & 10.78 & 28.93 & 0.010 \\
2009 & 12.51 & 8.70 & 27.44 & 0.958 \\
2010 & 14.51 & 10.10 & 28.72 & 0.276 \\
2011 & 14.81 & 10.39 & 29.43 & 0.168 \\
\hline
\end{tabular}

\subsubsection{Details}

2.3.3.1. Initialization. The model is initialized with 60,000 age $1+$ shovelnose sturgeon individuals on January 1st with 5-year burn-in simulations to minimize the effects of initial conditions. The initial location of each individual is randomly assigned to a grid cell with non-extreme habitat conditions with respect to water velocity $\left(\leq 0.6 \mathrm{~m} \mathrm{~s}^{-1}\right)$ and depth $(\geq 0.5 \mathrm{~m})$. We assume that the initial age structure follows the Poisson distribution with mean age of 7, which is truncated at a maximum age of 16 (shovelnose sturgeon >age 16 are rarely observed in the LPR, Pegg pers. observations), and that the initial sex ratio is 1:1. Age and sex are randomly assigned to each individual assuming that these variables follow a binomial distribution. For age 1+ sturgeon, initial lengths at age $i\left(t_{\text {age }}\right)$ are set to those at the end of the previous year's growing season (age $i-1$ ) and calculated using the von Bertalanffy growth function as

$$
L_{\text {fish int }}=L_{\text {fish } \infty} \times\left(1-e^{-K_{L}} \times\left(\left(t_{\text {age }}-1\right)-t_{0}\right)\right)
$$

where $L_{\text {fish } \infty}$ is the asymptotic average length, $K_{L}$ is the Brody growth rate coefficient (year ${ }^{-1}$ ), and $t_{0}$ is a constant (Appendix B (Supplementary material), Ricker, 1975).

Young-of-the-year (YOY) are introduced only after spawning, hatching, and settlement. Once spawned, fertilized eggs are initialized as super-individuals $\left(\mathrm{SI}_{\mathrm{YOY}}\right)$; the number of SIYOY is the number of spawning females, and the number of individuals that each SI represents is the total number of eggs spawned by each female. These values thus vary among females every simulation year. After settlement, the initial length $\left(L_{\text {larvaint }}\right)$ of $15.6 \mathrm{~mm}$ TL $( \pm 0.84 \mathrm{SE})$ is assigned to larvae (Braaten et al., 2008) as $L_{\text {larvaint }}=15.6+0.84 R N$, where $R N$ is a random number drawn from the normal distribution. Initial total mass is calculated using structural mass based on a length-dependent function with the assumption that sturgeon initially have optimally allocated energy in storage tissue (see Growth submodel in Appendix A (Supplementary material) for the formulation).

In each simulation year, initial prey biomass in each grid cell is randomly assigned on January 1st with a mean of 18.8 wet $\mathrm{g} \mathrm{m}^{-2}( \pm 2.2 \mathrm{SE})$, which was derived from field studies conducted near the study system (the Platte and Missouri Rivers, Hay et al., 2008; Whiles and Goldowitz, 2001; Whiles and Goldowitz, 2005) with a wet to dry weight conversion factor of 0.145 (Cummins and Wuycheck, 1971).

2.3.3.2. Submodels. The SEIBM- $1 \mathrm{D}_{\mathrm{SNS}}$ consists of one prey submodel (Drift invertebrate production) and six sturgeon submodels (Embryonic and larval development, Foraging, Movement,
Growth, Spawning, and Mortality) with a total of 72 parameters. Detailed description of these submodels is provided in Appendix A (Supplementary material).

\subsection{Model parameterization and calibration}

We initially parameterized the model with literature-derived parameter values (Appendix B (Supplementary material)) and then calibrated the submodel and full model with historical field data of the LPR population of shovelnose sturgeon (Peters and Parham, 2008; Schwarz et al., 2006; Swigle, 2003) using the pattern-oriented modeling (POM) approach (Grimm and Railsback, 2012). We simultaneously used the following four patterns from field observations; (a) length-at-age, (b) mass-at-age, (c) spatial distribution, and (d) age 3+ population size as model calibration filters. During calibration, we ran simulations continuously for 10 years (with the 1995-2004 LPR input data, Figure 2, Table 1, and Appendix C (Supplementary material)) with the corresponding LPR environmental input data and then compared mean simulated values ( $n=$ q10 replicates) with field observations, where available.

We calibrated the age $3+$ population size by iteratively running simulations after incrementally adjusting the initial population size and mortality parameters $\left(\alpha_{Z \text { pred }}\right.$ and $\beta_{Z \text { pred, }}$, see Appendix A and B (Supplementary material)) so that simulated population size remained within the bounds estimated from the field surveys conducted during 2001-2004 in the LPR (estimated population size: 23,000-69,000, Peters and Parham, 2008). We calibrated growth and energy allocation of age 1+ sturgeon to match field observations of length- and mass-atage of the LPR population by incrementally adjusting parameters of the Growth submodel $\left(a_{\rho^{\prime}} \beta_{\rho^{\prime}} a_{\text {grow, }}\right.$ and $\beta_{\text {grow, }}$ see Appendix A and B (Supplementary material)). We calibrated movement of feeding sturgeon to match field observations of seasonal spatial distribution (by relative biomass) of the LPR population (Hofpar, 1997; Swigle, 2003) by incrementally adjusting parameters of the Movement submodel $\left(t_{\text {move }}\right.$ and $P_{\text {mig }}$ see Appendix A and B (Supplementary material)).

\subsection{Simulation experiments}

\subsubsection{Sensitivity analysis}

To identify influential parameters in the model, we conducted sensitivity analysis for 72 parameters (Appendix B (Supplementary material)) simultaneously using Monte Carlo simulations (300 parameter sets) with the Latin Hypercube design. In these simulations, we assumed the normal distribution for all parameters with coefficient of variation (CV) of $1 \%$. We then computed correlations $(R)$ and relative partial sum of squares (RPSS, Rose et al., 1991) to determine proportional contributions of each parameter to variation in (a) total population size, (b) spawning stock biomass, (c) recruitment, (d) abundance of reproductive females, and (e) final body length of young-of-the-year.

\subsubsection{Model analysis: hindcasting (1995-2011)}

We ran simulation experiments ( $n=30$ replicates) with 17year (1995-2011) empirical time series data of water temperature and discharge (along with derived environmental data) in the LPR (Table 1 and Figure 2 ) to evaluate model structural validity and modeled population (and its components) sensitivity to seasonal and interannual variation in habitat conditions (e.g., river flow and prey availability). The 17-year inputs are grouped into three categories based on hydrological conditions (www.platteriverprogram.org); normal (2001 and 2007-2009), dry (2002-2006) and wet (1995-2000, 2010, and 2011) (Table 2). 

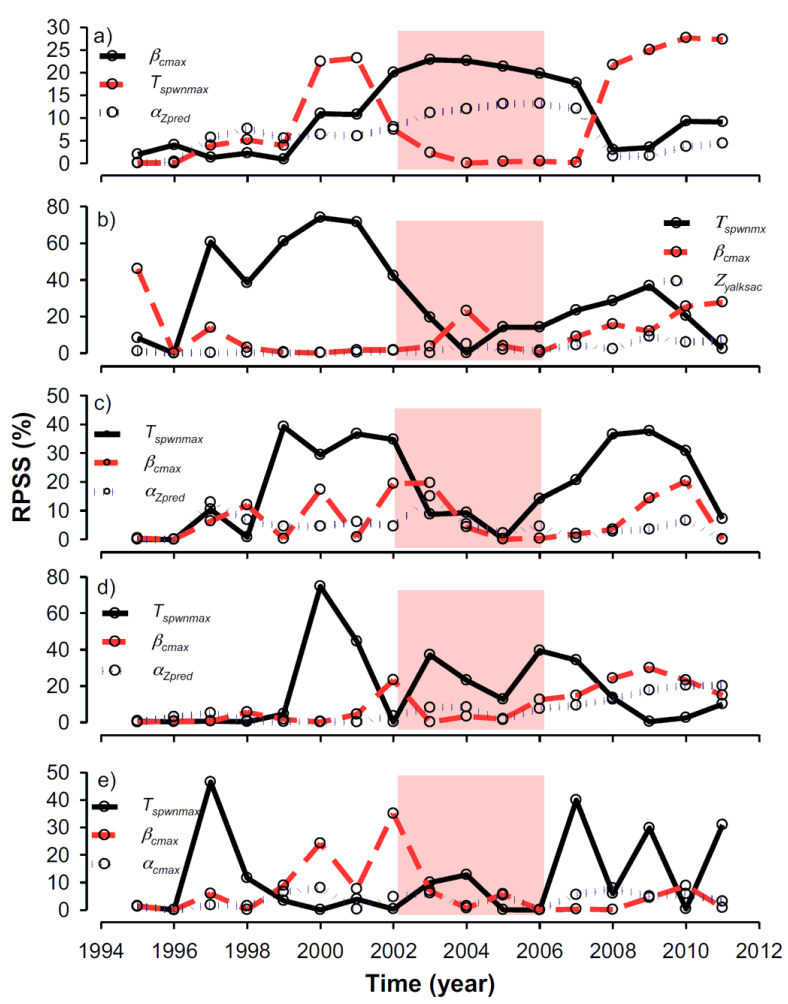

Figure 3. Results of sensitivity analysis (shown in relative partial sum of squares, RPSS). Each panel shows the top three parameters in the analysis in the 17-year simulations; (a) population size (number of individuals), (b) spawning female biomass (g wet), (c) recruitment (number of individuals); (d) reproductive females (number of individuals); and (e) final body length of young-the-year (mm). Note that parameters shown in colored lines are different for each state variables. Light pink rectangles indicate the drought period (2002-2006).

Table 2. Annual means of daily discharge rates of hydrological years in lower Platte River (1995-2011).

\begin{tabular}{llrrr}
\hline $\begin{array}{l}\text { Hydrological } \\
\text { class }\end{array}$ & Time (year) & $\begin{array}{r}\text { Annual } \\
\text { mean }\end{array}$ & Maximum & Minimal \\
\hline Normal & 2001, 2007-2009 & 153.24 & 989.08 & 9.82 \\
Wet & 1995-2000, 2010-2011 & 196.82 & 866.92 & 40.49 \\
Dry & $2002-2006$ & 83.24 & 284.57 & 0.00 \\
\hline
\end{tabular}

\subsubsection{Model evaluation}

To evaluate model applicability in projecting shovelnose sturgeon populations in the field, we evaluated the model (primary and secondary) predictions (Bart, 1995) using the POM approach (Grimm and Railsback, 2012) comparing five patterns in the simulated population. The state variables of the

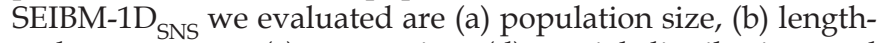
and mass-at-age, (c) maturation, (d) spatial distribution, and (e) age structure of shovelnose sturgeon with field observations in the LPR during the last three years of the simulation experiments (2009-2011; the sampling was conducted on March 17 to October 29 in 2009; March 30 to November 1 in 2010; and March 29 to August 31 in 2011; the maturation data were based on 2011 and 2012 samples; see Hammen, (2015) and Rugg, (2013) for details of field sampling and sample processing). We evaluated these patterns by comparing annual means of the 2009-2011 model outputs from the 17-year simulation experiments (above) with the field data using rootmean-square error (RMSE); we calculated RMSE values for each replicated simulation run $(n=30)$ and then used mean values of these replicates for model evaluation.

\section{Results}

\subsection{Sensitivity analysis}

There was relatively large interannual variation in parameter sensitivity for all five state variables examined, with recruitment being the most variable; population size $\left(N_{\text {pop }}\right.$; $\mathrm{CV}=3.43-111.3 \%)$, spawning stock biomass $(S S B ; C V=11.5-$ $100.3 \%)$, recruitment $\left(R_{\text {YOY }} ; C V=35.0-323.3 \%\right)$, the number of reproductive females $\left(N_{\text {reprof }} ; \mathrm{CV}=3.5-74.9 \%\right)$, and body length of young-of-the-year $\left(L_{Y O Y} ; C V=4.2-41.0 \%\right)$ during 1995-2011. All these variables consistently showed high sensitivity to a few parameters; in particular, one of the parameters that determine spawning habitat conditions, maximum spawning temperature threshold $\left(T_{\text {spwnmax }}, N_{\text {pop }}\right.$ : RPSS $=4.0$ $28 \%, S S B:$ RPSS $=34-72 \%, R_{\text {YOY }}: \operatorname{RPSS}^{\mathrm{R} w n m a x}=20-27 \%, N_{\text {reprof }}$ : RPSS $=4.0-66 \% ; L_{Y O Y}:$ RPSS $\left.=0.2-29 \%\right)$ and one of the parameters that limit daily food consumption, the exponent of maximum daily food consumption rate $\left(\beta_{\mathrm{cmax}}, N_{\mathrm{pop}}\right.$ : RPSS $=2.0$ $23 \%$, SSB: RPSS $=21-30 \%, R_{\text {YOY }}:$ RPSS $=4.0-11 \%, N_{\text {reprof }}$ RPSS $=1.0-20 \% ; L_{\text {YOY }}:$ RPSS $\left.=0.1-24 \%\right)($ Figure 3$)$. However, the sensitivity of the five state variables also showed high interannual variation (Figure 3); for example, both $S S B$ and $R_{Y O Y}$ are less sensitive to $T_{\text {spwnmax }}$ and $\beta_{\text {cmax }}$ during the dry years (2002-2006, Figure 3).

\subsection{Model analysis: hindcasting hydrological influences on individual-to-population traits}

Our model simulations showed that spatiotemporal dynamics of river hydrology played a major role in sturgeon population dynamics including timing and location of spawning events as well as growth and survival of larvae.

\subsubsection{Population dynamics}

Total population biomass of sturgeon declined by 4- to 7-fold during dry years (2002-2006, Figure 4a); similarly, total population size declined by 3 - to 4 -fold (Figure $4 \mathrm{~b}$ ). Juvenile abundance steadily declined throughout the dry years and post-dry years until 2008, whereas adult abundance did not start declining until 2006 (Figure 4c). In the post-drought period, total population size and biomass, and juvenile abundance all bounced back, whereas adult abundance continued declining (Figure 4c).

\subsubsection{Spatial distribution and movement}

Movements and habitat selection of sturgeon varied considerably among years, reflecting hydrological variation (Figure 5). Annual means of daily movement rate of age 1-16+ were $377-748 \mathrm{~m} \mathrm{~d}^{-1}$. Juvenile and adult sturgeon generally moved downstream during spring and early summer and then moved upstream in fall; however, during the dry years, more individuals congregated in the downstream than during normal or wet years.

Mean longitudinal locations of spawning events also shifted downstream in response to river discharge (mean flow rates during the spawning period: early April to late July: $109.8 \mathrm{~m}^{3} \mathrm{~s}^{-1}$ in dry years, $200.3 \mathrm{~m}^{3} \mathrm{~s}^{-1}$ in normal years, and $221.2 \mathrm{~m}^{3} \mathrm{~s}^{-1}$ in wet years); $122.7 \mathrm{rkm}$ in dry years, $106.8 \mathrm{rkm}$ in normal years, and $93.2 \mathrm{rkm}$ in wet years (Figure 5). Further, variability in spawning locations declined ( $\mathrm{SD}=12.6-19.2)$ in dry years compared to normal or wet years (SD $=21.2-38.3$, Figure 5). Mean settlement locations of drifting larvae were also highly variable between $\sim 90$ and $130 \mathrm{rkm}$ of the river with a few exceptions (1997 and 2006), and then shifted upstream ( $50 \mathrm{rkm})$ during high flow events in 2008 and 2010 (Figure 5). 


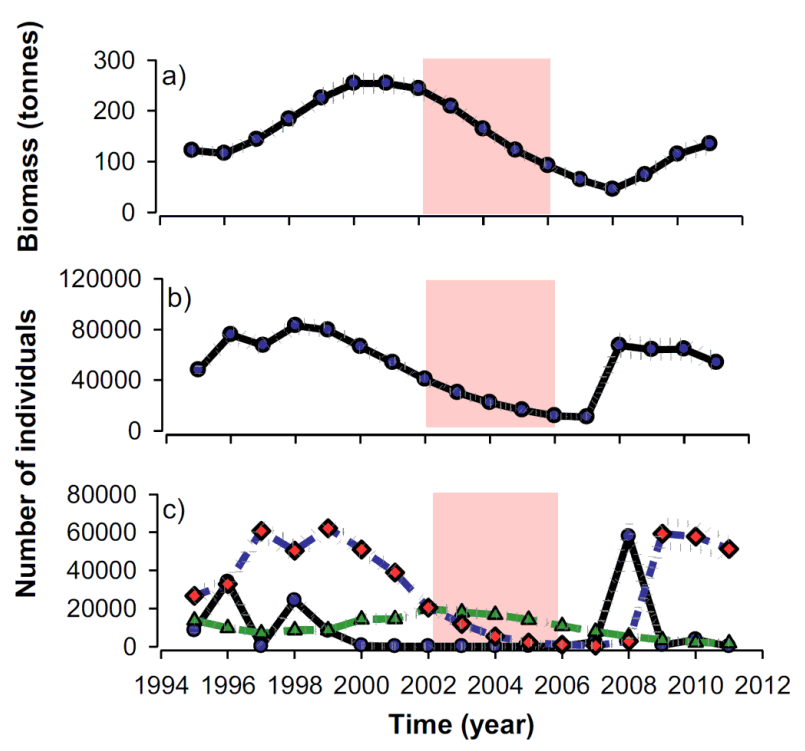

Figure 4. Interannual variation in simulated (a) total biomass, (b) total abundance, and (c) young-of-the-year (black solid line), juvenile (blue long dashed line), and adult (green short dashed line) abundance of the LPR shovelnose sturgeon at the end of each simulation year during 1995-2011. Dark gray dotted lines indicate 95\% confidence lines based on 30 replicated simulations. Light pink rectangles indicate the drought period (2002-2006).

\subsubsection{Foraging and energetics}

During dry years, mature females consumed less than during normal or wet years (Figure 6a). Further, mature females in the reproductive cycle allocated a higher proportion of energy to storage in dry years than in normal or wet years, resulting in less energy available for gonad development (Figure $6 \mathrm{~b}$ ). This shift in energy allocation allowed these females to maintain their physiological condition (Figure 6c). However, reduced energy intake led to reduced somatic growth rates during dry years compared to wet or normal years (Figure $6 \mathrm{~d}$ ). During the post-drought period, reproductive females allocated more energy to gonad than to storage (Figure 6b). By contrast, immature and non-reproductive mature females did not show any difference in energy allocation in response to river hydrology (Figure 6e).

\subsubsection{Maturation and spawning}

River hydrology also altered reproductive life-history traits of females. Females matured earlier (by 1-2 years) during dry years than normal or wet years (Figure 7a). While the biomass of spawners did not decline until 2008 ( 220-1100 females spawned throughout dry years, Figure $7 \mathrm{~b}$ ), the proportion of reproductive females that spawned declined to less than $\sim 20 \%$ during dry years (Figure 7 c).

Age structure of spawning females shifted during dry years; $>90 \%$ of spawners consisted of age 9 fish in 2004-2006 (Figure $7 \mathrm{~b}$ ). However, the relative number of mature females in the reproductive cycle did not start declining until 2006 (Figure 7d). Mean and variation of spawning frequency of females declined during dry years and remained low during the post-drought period (Figure 7e); whereas, annual mean egg production varied little among years in response to river hydrology (Figure 7f).

\subsubsection{Recruitment}

Interannual variation in hydrological conditions played a major role in year-class strength by reducing growth and

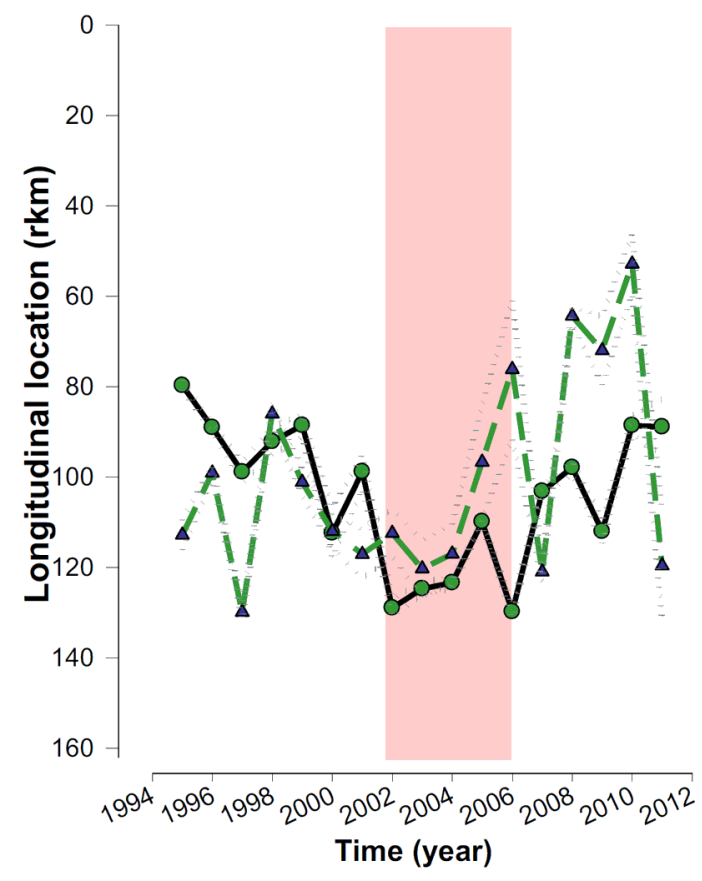

Figure 5. Mean longitudinal distribution (river km or rkm) of simulated shovelnose sturgeon spawning events (black solid line) and larval sturgeon settlement (green long-dashed line) locations in the LPR during 1995-2011. Dark gray dotted lines indicate 95\% confidence lines based on 30 replicated simulations. Light pink rectangle indicates the drought period (2002-2006).
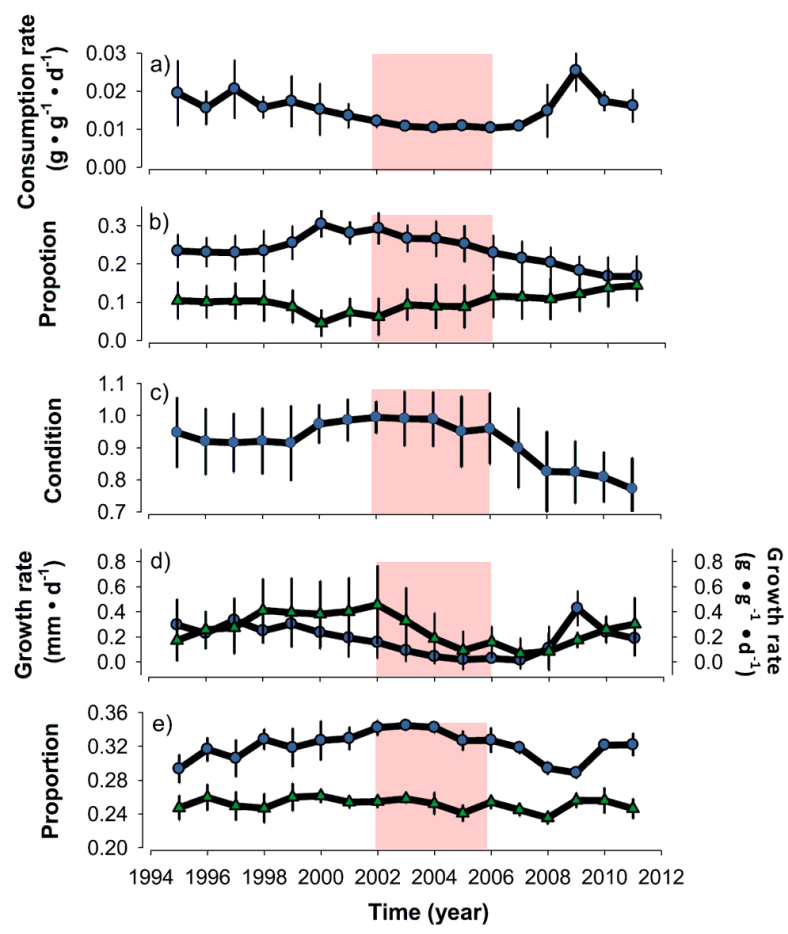

Figure 6. Interannual variation in (a) food consumption rate of reproductive females, (b) relative mass of storage (black solid circles) and gonad (red solid triangles) of reproductive females, (c) physiological condition of reproductive females, (d) growth rate in length (blue solid circles) and mass (green solid triangles) of reproductive females, and (e) relative storage mass of juvenile (blue solid circles) and non-reproductive (green solid triangles) females during 1995-2011. All error bars indicate standard deviation among individual females based on one simulation run randomly selected from 30 replicates. Light pink rectangles indicate the drought period (2002-2006). 


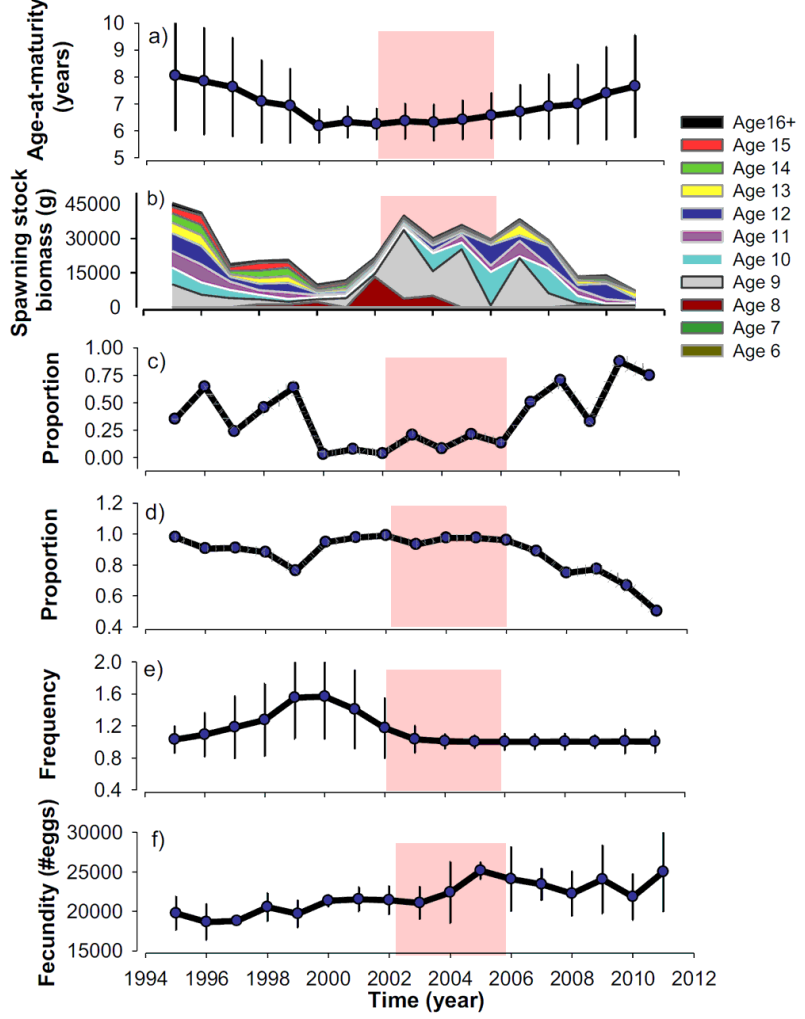

Figure 7. Interannual variation in (a) mean age-at-maturity of females, (b) spawning stock biomass, (c) relative number of reproductive females that spawned, (d) relative number of mature females in the reproductive cycle, (e) mean frequency of lifetime spawning events, and (f) mean fecundity of the simulated shovelnose sturgeon population during 1995-2011. Error bars in (a), (b), (e), and (f) indicate standard deviation among individual females based on one simulation run randomly selected from 30 replicates. Dark gray dotted lines in (c) and (d) indicate $95 \%$ confidence lines based on 30 replicated simulations. Light pink rectangles indicate the drought period (2002-2006).

survival of post-settlement sturgeon. Despite continued spawning during dry years, the mean number of recruits declined by $>950$-fold $\left(\sim 3.7 \times 10^{-7}\right.$ individuals $\left.\mathrm{m}^{-2}\right)$ and remained low until the end of the dry period (Figure 4c). Most YOYs died from size-dependent predation; highest mortality rates (5.5- and 14.8-fold higher than in other years) were observed in 2002 and 2006 (Figure 8a).

Growth and survival of YOYs varied highly among hydrological years. Surviving YOYs consumed more (by $>3-$ fold) food, grew larger (by 1.3-fold in length), and ultimately reached larger body sizes during dry years (Figure $8 b-d$ ). Consumption rates of YOYs were strongly influenced by water current and drift prey density; YOYs consumed the most efficiently when water current was $0.24-0.37 \mathrm{~m} \mathrm{~s}^{-1}$ and drift prey density was $5.9-8.7 \mathrm{~g} \mathrm{~m}^{-2}$ (Figure $8 \mathrm{e}$ ).

\subsection{Model evaluation: comparison with field observations}

\subsubsection{Spatial distribution}

The simulated spatial distributions of shovelnose sturgeon in the LPR generally correspond to the field observations during April-November of 2009-2011 (Table 3, RMSE = 0.116-1.74). A majority of observed and simulated sturgeon were found in the downstream between Louisville and Plattsmouth, NE ( 84$162 \mathrm{rkm}$ ) of the river, where flow-dependent HSI, river connectivity, and drift prey biomass were all relatively high. There were however some notable discrepancies between simulated
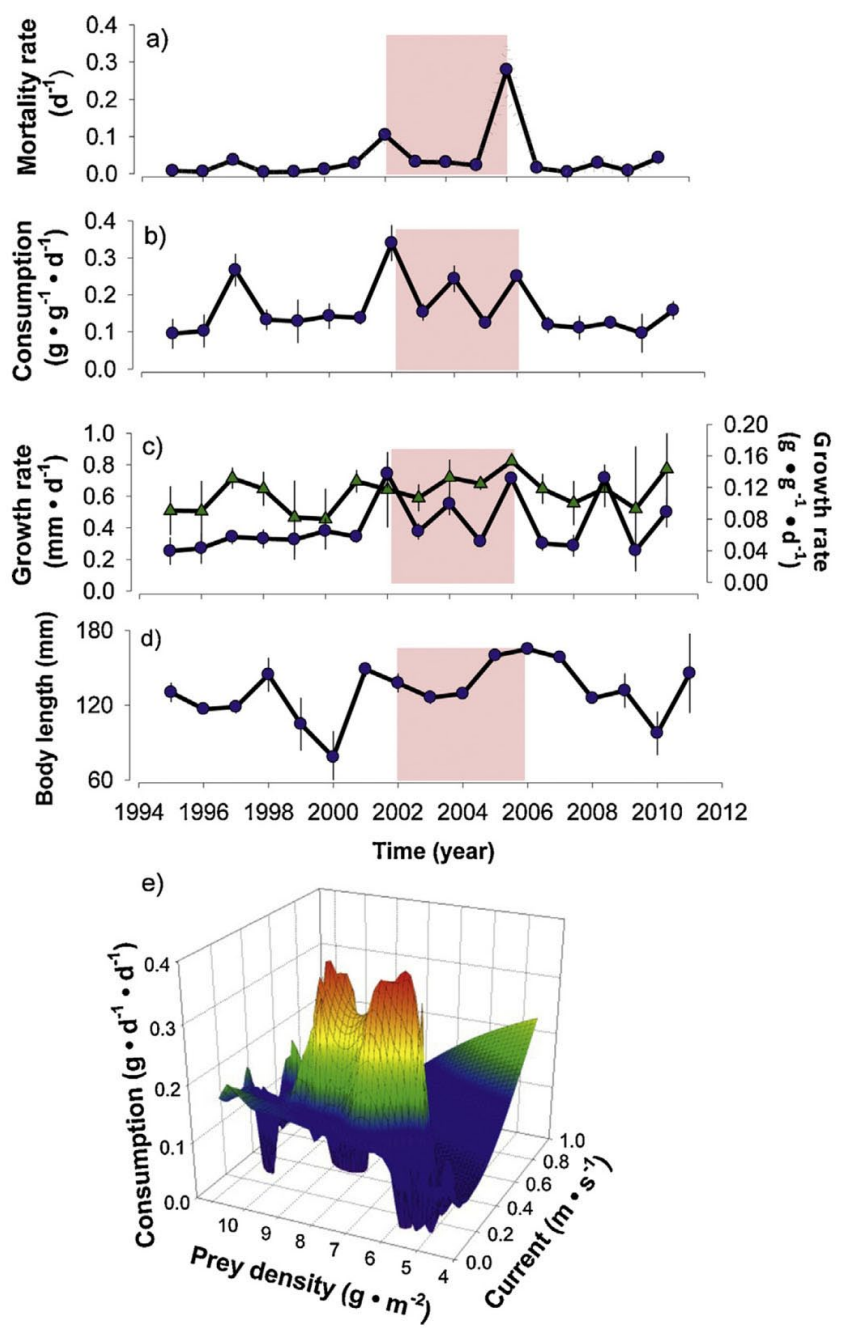

Figure 8. Young-of-the-year shovelnose sturgeon's (a) interannual variation in size- dependent predation mortality, (b) interannual variation in food consumption, (c) interannual variation in growth rate in length (blue solid circles) and mass (green solid triangles), (d) interannual variation in body length at the end of the growing season, and (e) relationship between consumption and drift prey density and water current during 1995-2011. All error bars indicate standard deviation among individual larvae based on one simulation run randomly selected from 30 replicates. Light pink rectangles indicate the drought period (2002-2006).

and observed spatial distributions; in particular, a larger number of simulated sturgeon moved upstream (50-76 rkm) during fall than observed sturgeon in the LPR (Table 3).

\subsubsection{Growth}

Simulated mean length-at-age (age 3-14) during the growing season matched field observations during 2009-2011 (Figure $9 \mathrm{a}-\mathrm{c}$ ). The mass-length relationship of simulated sturgeon also matched that of observed sturgeon in the LPR during 2009-2011 (Figure 9d-f).

\subsubsection{Maturation and fecundity}

Simulated age-at-maturity of females matched field observations (age-at- $50 \%$ maturity $=\sim 9-10$ years old, Figure 10). Observed age-at-maturity of males estimated by the logistic function appeared to mature slightly ( 1 year) later than simulated males; however, age-at-maturity of both simulated and observed male sturgeon was highly variable (Figure 10). 
Mean fecundity (the number of eggs per female) in simulated females $(23,627.8 \pm 4063.3)$ was higher than field observations (16,097.8 \pm 6239.1; minimum-maximum: 9301-37,513).

\subsubsection{Age structure and population size}

Observed age distributions during 2009-2011 showed little interannual variation, which differed from simulated age distributions (Figure 11). Underrepresented age classes (by $\sim 44.8 \%$ ) in the simulated population were year classes with low recruitment particularly during dry years (Figure 11).

Underrepresentation of some age classes in the simulated population was reflected in population size, being smaller (by $\sim 38.8 \%$ ) than the observed population during 2009-2011, which resulted in large RMSE values $\left(\mathrm{RMSE}_{2009-2011}=39.0\right.$,

Table 3. Observed and mean simulated seasonal spatial distributions of shovelnose sturgeon in four segments (1-50, 50-76, 76-128, and 128$162 \mathrm{rkm}$ ) of the lower Platte River during 2009-2011. RMSE = root-mean-square error.

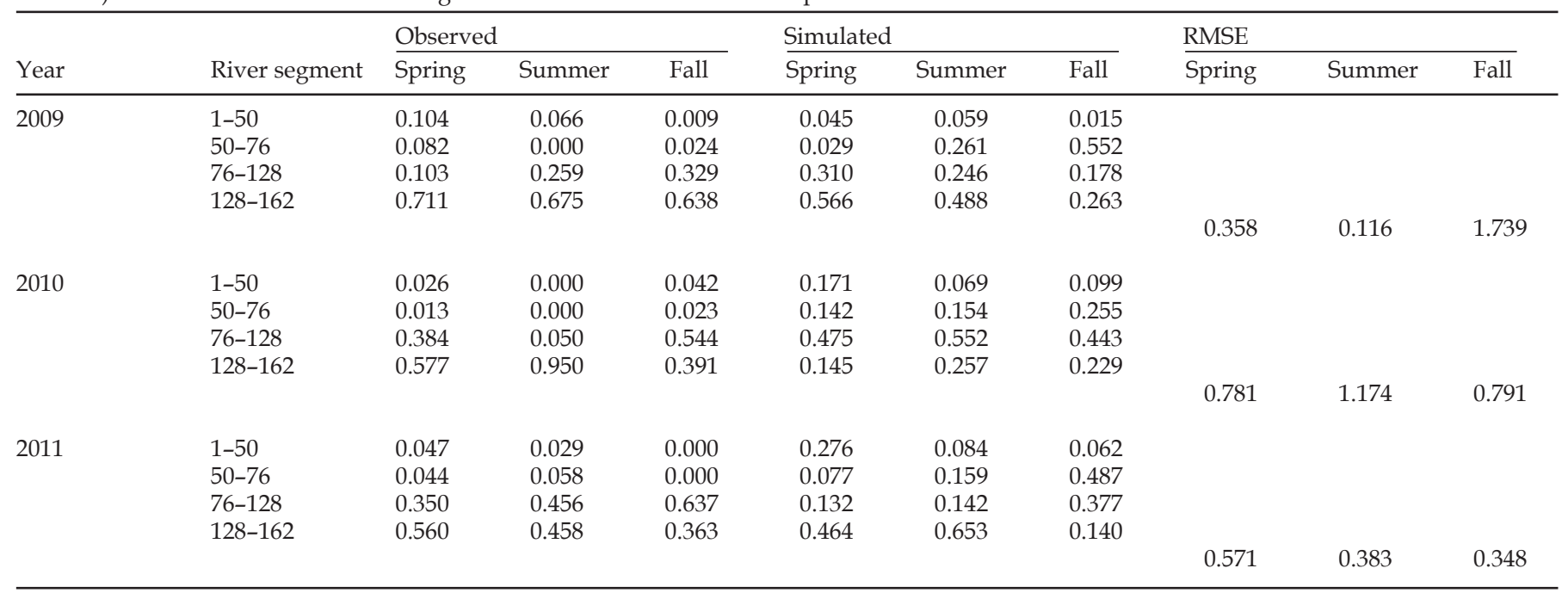

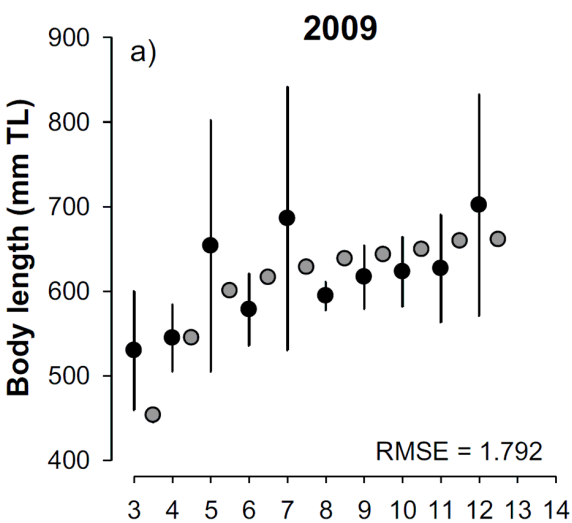

2009

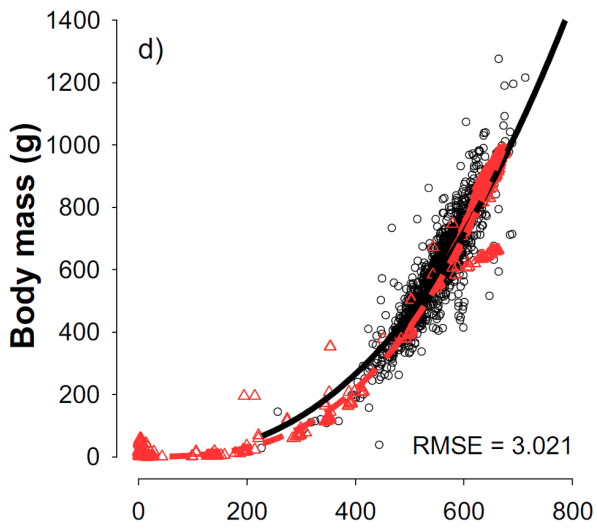

b)

- Observed

- Simulated

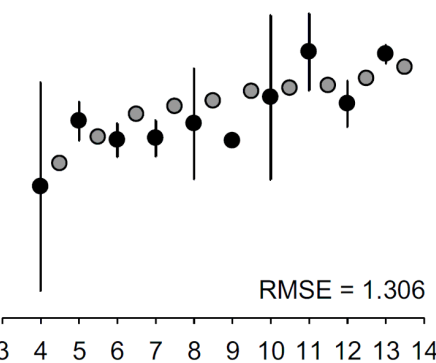

Age (years)

2010

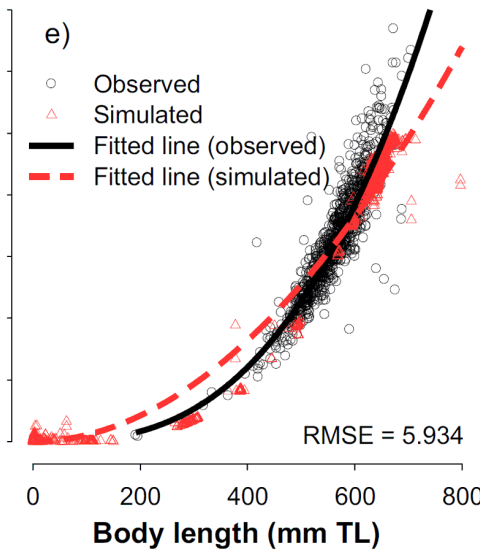

c)

2011

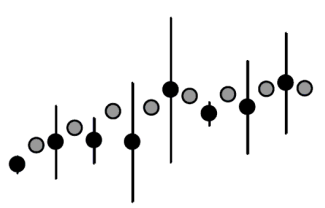

RMSE $=1.077$

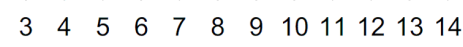

2011

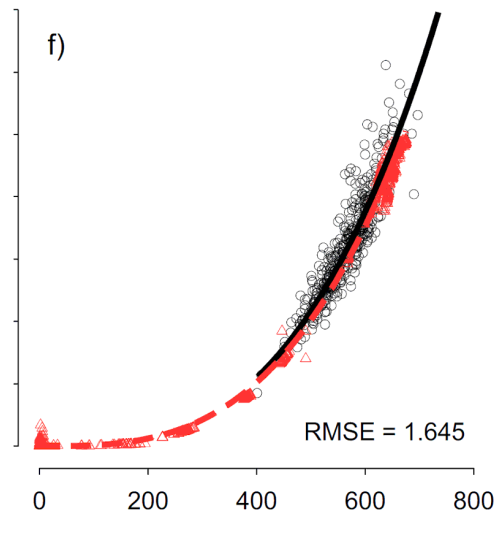

Figure 9. Simulated and observed total body length (TL) of age 3+ shovelnose sturgeon in the lower Platte River in (a) 2009, (b) 2010, and (c) 2011; and simulated and observed body mass-length relationship of age 3+ shovelnose sturgeon in the lower Platte River in (d) 2009, (e) 2010, and (f) 2011. Error bars in observed values in $(\mathrm{a}-\mathrm{c})$ indicate standard deviation. Black solid lines and red dashed lines in (d-f) indicate a power function (body mass $=a \times$ length $^{\beta} ; \boldsymbol{a}$ and $\beta$ are constants) fitted to simulated data and observed data, respectively. 


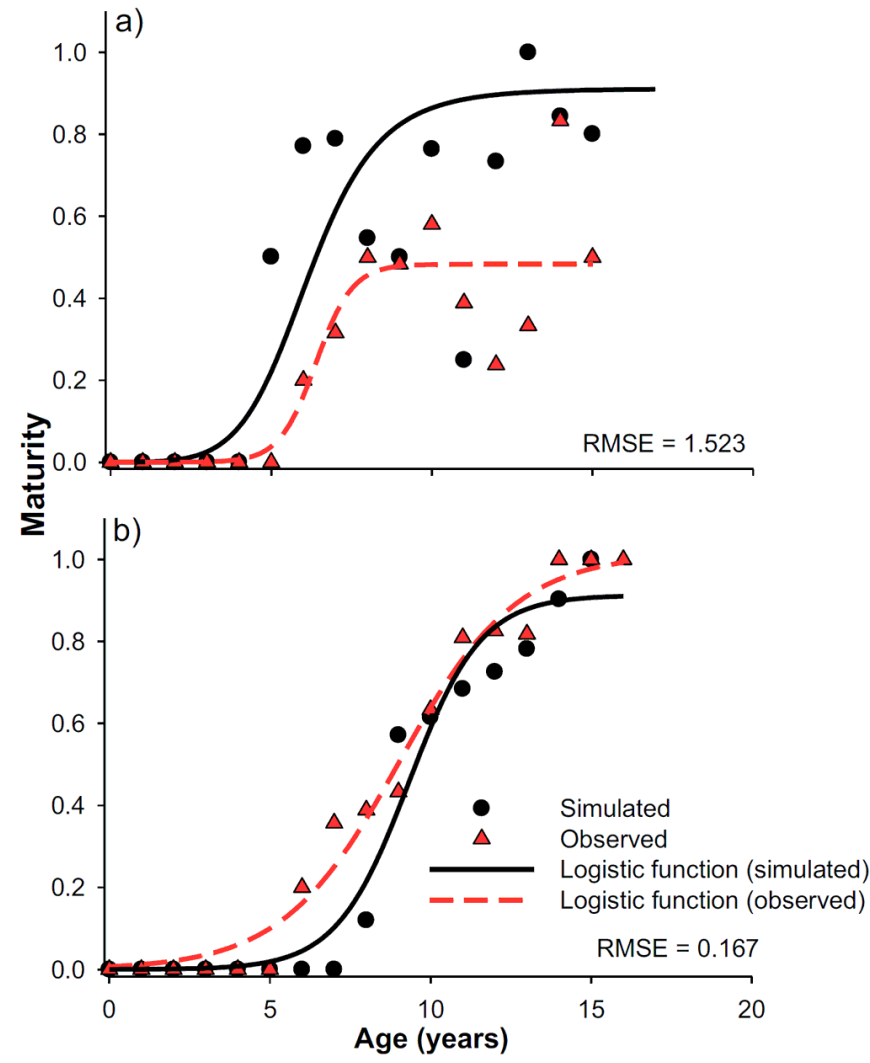

Figure 10. Simulated and observed age-at-maturity of (a) male and (b) female shovelnose sturgeon in the lower Platte River. Black circles and red triangles indicate simulated and observed data (pooled from 2011 and 2012 sampling), respectively. Black solid lines and red dashed lines in $(a-b)$ indicate a logistic function fitted to simulated data and observed data, respectively.

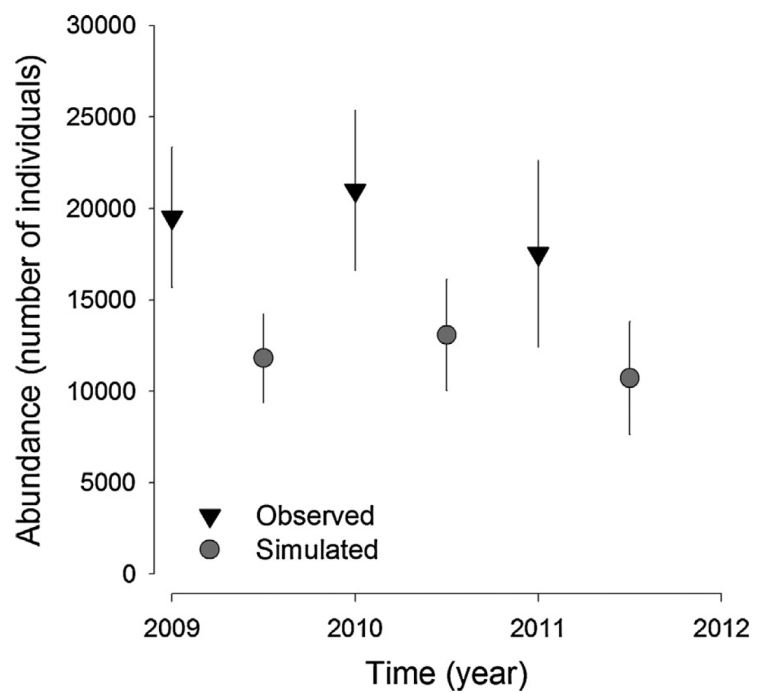

Figure 12. Simulated and observed mean ( \pm standard deviation, SD) age $3+$ population size of shovelnose sturgeon in the lower Platte River during 2009-2011.

38.7, and 36.4, respectively Figure 12), while low interannual variation $\left(\mathrm{CV}_{\text {model }}=0.085\right)$ in the simulated population was consistent with field observations $\left(\mathrm{CV}_{\text {field }}=0.090\right.$, Figure 12).

\section{Discussion}

\subsection{Model simulation analyses}

Our model simulations demonstrated that seasonal and interannual variation in hydrological conditions drives timing, location, and magnitude of spawning and recruitment success of shovelnose sturgeon in regulated rivers such as the lower Platte River (LPR). During our study period (1995-2011), the

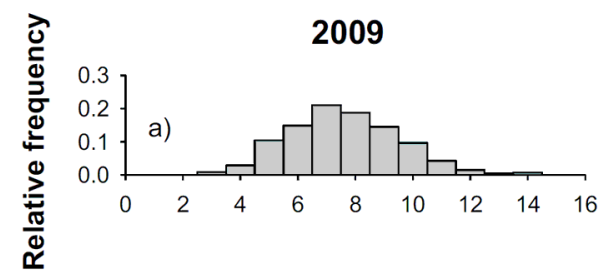

2009

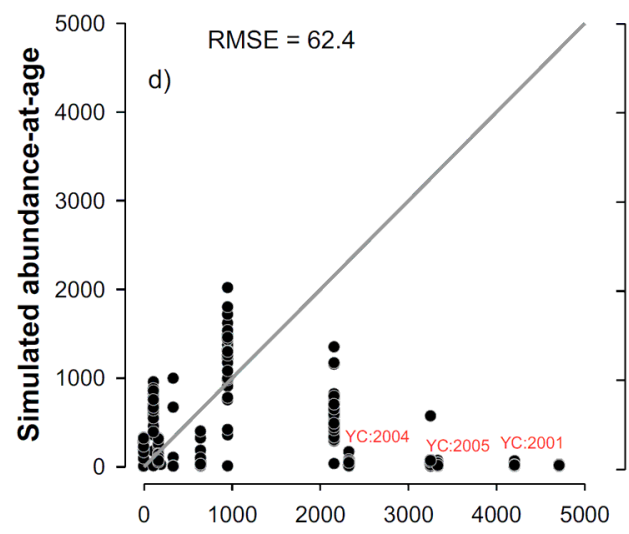

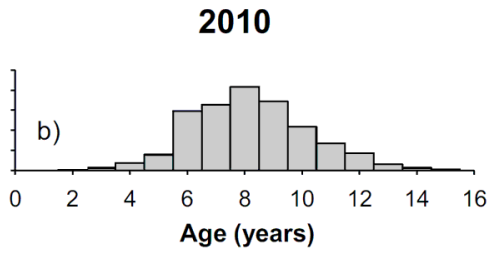

2010

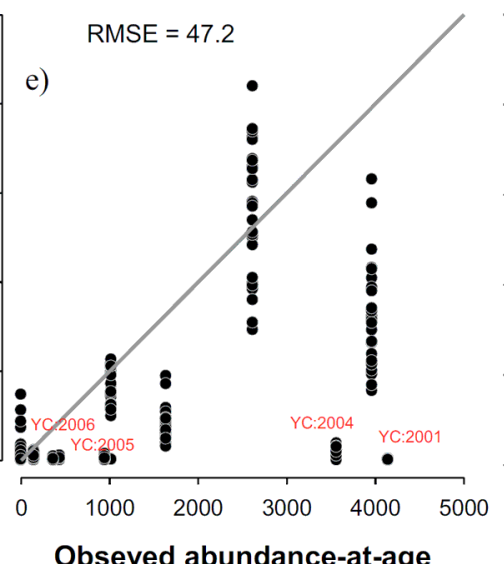

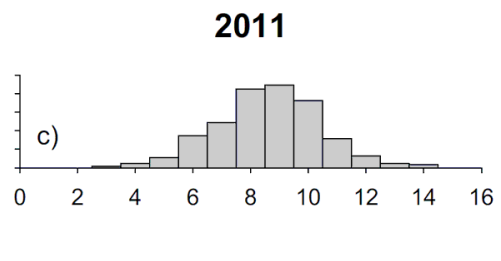

2011

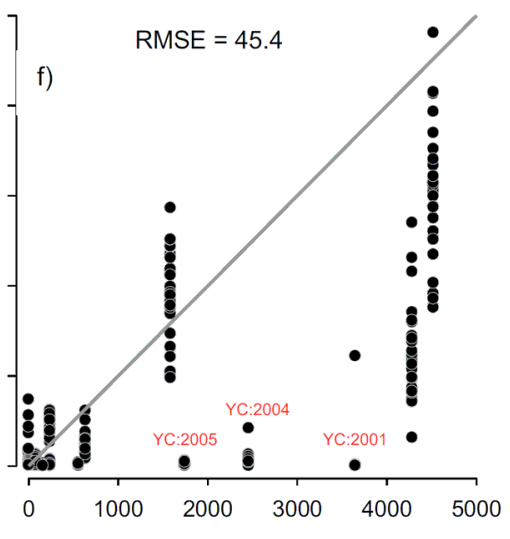

Figure 11. Observed age structure of shovelnose sturgeon in the lower Platte River in (a) 2009, (b) 2010, and (c) 2011; and comparison between simulated and observed abundance-at-age of shovelnose sturgeon in (d) 2009, (e) 2010, and (f) 2011. Year classes (YC) with total or near-total recruitment failures in model simulations are labeled in the figure. 
model showed that the weakest year-classes (2004 and 2006) and strongest year-classes (1998 and 2008) occurred in the driest and wettest years, respectively. During the normal and wet years, river flow rate is consistently above $\sim 120 \mathrm{~m}^{3} \mathrm{~s}^{-1}$, maintaining more than $65 \%$ of mean river connectivity with good habitat quality (mean habitat suitability or Disc $\mathrm{Fi}_{\mathrm{Fi}}=0.38-0.41$ ). These conditions appear to be suitable for reproductive female sturgeon to migrate and spawn, and likely for young-of-theyear (YOY) sturgeon to move freely, and forage and grow efficiently during the growing season (May-October).

A persistent drought period (2002-2006; annual mean discharge rates below $100 \mathrm{~m}^{3} \mathrm{~s}^{-1}$ ) however produced some areas with extreme low flow conditions (mean river connectivity dropping to less than $40 \%$; mean Disc $_{\mathrm{Fi}}=0.22$ ) that are unlikely to be suitable for sturgeon spawning and rearing. During this period, simulated sturgeon consistently exhibited total or near total recruitment failures; these consecutive weak year-classes resulted in a steady decline (by $86 \%$ of the mean pre-drought period population size) by the end of the drought period in 2006. Furthermore, low or lack of recruitment during the drought period resulted in shifts in population demographics; the simulated population increasingly consisted of older individuals. After the drought period, however, because of strong year-classes produced in 2008 and 2010, the population primarily consisted of recently recruited individuals. We discuss potential mechanisms underlying interannual recruitment variability via dynamic interactions of environmental and biological processes below.

\subsubsection{River hydrology influences on spawning behavior}

River hydrology has been hypothesized to play a critical role in fish spawning behavior and larval survival (e.g., DeLonay et al., 2007; Peterson and Kwak, 1999; Phelps et al., 2010). Field studies suggest that hydrological conditions such as flow and connectivity appear to drive spawning behavior (e.g., migration and congregation) of shovelnose sturgeon (Tripp et al., 2009), but other environmental cues such as water temperature and photoperiod or internal biological rhythms may be equally important for spawning events (Papoulias et al., 2011).

One hypothesized mechanism underlying recruitment failure during droughts is lack of spawning (DeLonay et al., 2009). The importance of river flow in spawning behavior has been documented for many stream fishes including sturgeon (Flowers et al., 2009; Paragamian and Wakkinen, 2011). In our model, habitat quality based on river flow and drift prey density determines movement and habitat selection probability by sturgeon, and ultimately spawning events. Model simulations showed that while the numbers of spawners in the drought period did not differ from those in normal or wet years, there were more females who were reproductively ready but did not spawn in the drought period. Persistent low flow conditions in early spawning season of the drought period forced many gravid females to migrate to and congregate downstream, where flow rates are occasionally high enough during the spawning season for some gravid females to spawn. The role of river discharge in sturgeon spawning may thus serve only as a temporal trigger for the beginning of the spawning season (Goodman et al., 2013; Tripp et al., 2009), and other environmental drivers such as water temperature may drive spawning behavior by facilitating physiological processes (e.g., energy allocation) in the final stage of gonad maturation prior to spawning (DeLonay et al., 2007).

Sensitivity analysis indicated the importance of water temperature in population, spawning, and recruitment dynamics (i.e., maximum spawning temperature), influencing the number of spawners and year class strength in a given year. While the natural flow regime is a reliable cue to initiate spawning for riverine fish such as shovelnose sturgeon to anticipate favorable conditions for spawning in late spring to early summer, water temperature, which directly affects a variety of physiological processes, appears to strongly influence population-level state variables. Sensitivity to the biological parameters examined also varied over time along with changes in the flow regime; during the dry years, state variables such as spawning biomass and recruitment became less sensitive to the biological parameters, indicating the importance of environmental variation such as flow regimes for shovelnose sturgeon population dynamics.

In addition to being dispersal and spawning cues, river flow also directly influences foraging of stream organisms (Hart and Finelli, 1999; Spindler et al., 2012). Low flow conditions caused by flow regulation may reduce prey availability and foraging efficiency of drift-feeding predators (Poff et al., 1991). In our model, the combination of low flow conditions and low drift prey production during the drought period limited foraging opportunities and in turn facilitated shifts in energy allocation particularly in adults; reduced energy intake lowered energy availability for storage and gonad tissues, slowing growth and gonad development in mature females. Habitat selection, especially during the drought period, may therefore be a critical process for growth and survival (Hayes et al., 2000; Spindler et al., 2012), and ultimately reproductive success of drift-feeding predators (Schlosser, 1998).

Energy allocation to growth and reproduction in organisms with indeterminate growth may suggest dynamic tradeoffs to optimize fitness (Heino and Kaitala, 1999; Skjæraasen et al., 2012); this life-history strategy also applies to sturgeon and paddlefishes (Scarnecchia et al., 2007). Reduced energy intake in stressful environments such as low flow conditions can slow gonad development (Stead et al., 1999) and delay maturation, potentially leading to skipped spawning and ultimately fewer lifetime spawning events (Rideout and Tomkiewicz, 2011; Secor, 2008). Our model simulations showed that gravid females were unable to obtain enough food to allocate sufficient energy to gonads because of low flow conditions and drift prey availability during the drought period. However, while some gravid females with poor condition aborted the reproductive cycle in the drought period, the number of females that skipped spawning remained relatively low $(<1 \%)$. Low flow conditions only slowed gonad development and reduced the number of spawning females during the drought period, but these conditions were not severe enough to force the majority of gravid females to abort the reproductive cycle. Females who aborted the reproductive cycle reallocated energy to storage; this energy reallocation in fact improved their physiological condition and thus likely prevented starvation mortality.

\subsubsection{River hydrology influences on larval sturgeon}

Habitat choices by spawning adults may determine the fate of their young (Houde, 2009; Humphries et al., 1999; King et al., 2003; Mion et al., 1998). Because of high vulnerability to extreme flow events, river flow can have larger effects on growth and survival of larval sturgeon than on juveniles and adults (Humphries et al., 1999). Our simulations showed that the main cause of mortality of model YOY sturgeon in the drought period was size-dependent predation during the initial post-settlement period. In the drought period, post-settlement larval sturgeon were unable to efficiently feed enough to grow out of a size-dependent 'predation window' (Claessen et al., 2002) because of low flow and low drift prey density. Further, increased density of spawning females within limited areas of the downstream may also have increased the likelihood of a large number of larvae settling in proximity (crowding), 
enhancing density-dependent effects on their growth and survival (i.e., increased competition for limited resources). Reduced foraging success, and in turn slowed growth rates, thus led to a large larval sturgeon mortality within the initial few weeks in our simulations. By contrast, YOY sturgeon who survived this 'critical period' grew more by the end of the growing season in the drought period than in wet or normal years; consecutive recruitment failures and declining population size likely relieved these YOYs from density-dependent effects (Cryer et al., 1986). Slow growth and low survival of post-settlement larvae thus appear to play a larger role than lack of spawning in recruitment failures of Scaphirhynchus spp. during drought periods.

\subsection{Model evaluation with field observations and model limitations}

Our sturgeon model reproduced observed patterns in growth, energetics (via physiological condition), maturation, and movement of the LPR population, whereas there were some discrepancies in age structure and in turn population size between observed and simulated populations. Some of the largest discrepancies in age-specific abundance were found in year classes from dry years, which suggest that (1) large changes in flow regimes may have less catastrophic effects on recruitment (higher survival of larval sturgeon) than projected; or (2) frequent migration between the LPR and the mainstem Missouri River can compensate large variation in demographics due to recruitment failure. Field observations however consistently suggest that lack of hydrological effects on sturgeon recruitment is unlikely (DeLonay et al., 2009). As observed in previous simulation studies on other riverine fishes (e.g., (Jager et al., 2001; Perry and Bond, 2009), these discrepancies may thus suggest frequent migration between the LPR and the mainstem, allowing the sturgeon population to maintain age structure and population size.

One major limitation in our model that may have prevented us from reproducing these patterns in population dynamics of shovelnose sturgeon is its spatial component. While the model reproduced observed seasonal patterns in population spatial distribution within the LPR, our model did not account for immigration of shovelnose sturgeon from the upstream segments (North and South) of the Platte River or the mainstem Missouri River to the LPR; we also assumed low emigration from the LPR (a semi-closed population). We also tracked only drifting larvae that settled within the LPR; those who left the LPR were treated as 'lost' from the population. While adult Scaphirhynchus spp. are relatively sedentary, field studies have shown that they may frequently migrate over long distances and likely move in and out of the LPR during the spawning season (DeLonay et al., 2009). The findings from other spatially explicit modeling studies on stream and riverine fishes suggest that river connectivity can determine habitat conditions for spawners and young-of-the-year fishes and in turn population sustainability of migratory species in regulated systems (Landguth et al., 2014; Marschall et al., 2011; Perry and Bond, 2009). Reducing uncertainty associated with spatial ecology of large migratory fishes such as Scaphirhynchus spp. including migration rate and potential metapopulation dynamics within the system (e.g., Jager et al., 2001) in future modeling and field studies may help improve our capability to predict and identify the importance of each tributary as spawning or nursery grounds for conservation and management purposes.
4.3. Management implications for riverine fish recruitment in regulated systems

Our model simulations demonstrated that both direct (dispersal and settlement) and indirect (energetics via drift prey production) effects of river flow regimes can interactively determine recruitment success of shovelnose sturgeon in regulated rivers, further emphasizing the role of hydrology in recruitment variability for stream and riverine fishes (Rosenfeld et al., 2012).

Managers of natural resources in regulated systems such as the LPR regularly face challenging tasks in managing potentially conflicting services that rivers provide (e.g., irrigation vs. endangered species conservation) (Gilliland et al., 1985). Our model simulations suggest that interannual variation in hydrological conditions is a key driver in long-term sturgeon recruitment variability; occasional extreme hydrological events such as droughts can severely reduce sturgeon spawning and recruitment potential. In particular, model simulations suggest that slow growth and in turn low survival of larval sturgeon likely play a larger role in recruitment failures during droughts than low or lack of spawning events. Prolonged low flow conditions during consecutive dry years observed in the LPR could thus for instance hamper the recovery process of endangered species such as pallid sturgeon. Similar effects of hydrology have been documented in theoretical and empirical studies on riverine species (e.g., Lake, 2003). In maintaining sustainable fish populations in regulated rivers, managers thus need to account not only for spring peak flow as a spawning cue for reproductive females but also a sustained level of flow for larvae to efficiently forage and grow to be recruited into the population.

Because long-lived iteroparous species such as sturgeon may have reproductive capacity to recover from persistent recruitment failures with occasional strong year-classes 'reserved' in adult populations (i.e., storage effect, Secor, 2008), they may persist for years with unfavorable hydrological conditions before becoming extinct. With expected changes in flow regimes (e.g., increased frequencies of floods and droughts) due to changes in climate (Palmer et al., 2008), it is increasingly imperative for scientists to understand and predict how flow regulation affects spawning behaviors and recruitment success, and inform managers to adjust actions that can accommodate expected changes in river flow regimes.

Rivers and streams provide a variety of ecosystem services (irrigation, navigation, hydroelectricity, etc. Wilson and Carpenter, 1999). With likely changes in water availability and use due to expected intensification of agricultural land use to meet demands of human food consumption (Mueller et al., 2012), we need to account for potential tradeoffs when managing valuable natural resources, e.g., water (agricultural land use, flood control, etc.) and conservation of threatened and endangered species with high socioeconomic value such as sturgeon (Dudgeon et al., 2006). Because of a variety of confounding factors (social, economic, and ecological costs for multiple stakeholders) involved in managing fish populations, a framework of adaptive management using a process-oriented modeling approach (such as in our study) could provide a valuable tool for managers to make ecologically sound trade-off decisions (Jacobson and Galat, 2008).

Acknowledgments - We greatly appreciate constructive discussion with Volker Grimm and John Conallin on earlier versions of the model, and comments by two anonymous reviewers and the Associate Editor on the earlier version of this manuscript. This project was partially funded by University of Nebraska-Lincoln and the Nebraska Game and Parks Commission (Project F-180-R). 
Appendix A - Appendix D (Supplementary data) can be found following the References.

\section{References}

Anderson, J.T.,1988. A review of size dependent survival during prerecruit stages of fishes in relation to recruitment. J. Northwest Atlantic Fish. Sci. 8, 55-66.

Bart, J., 1995. Acceptance criteria for using individual-based models to make management decisions. Ecol. Appl. 5, 411-420.

Boehlert, G.W., Mundy, B.C., 1988. Roles of behavioral and physical factors in larval and juvenile fish recruitment to estuarine nursery areas. Am. Fish. Soc. Symp. 3, 51-67.

Braaten, P.J., Fuller, D.B., Holte, L.D., Lott, R.D., Viste, W., Brandt, T.F., Legare, R.G., 2008. Drift dynamics of larval pallid sturgeon and shovelnose sturgeon in a natural side channel of the upper Missouri River, Montana. North Am J. Fish Manag. 28, 808-826.

Bunn, S.E., Arthington, A.H., 2002. Basic principles and ecological consequences of altered flow regimes for aquatic biodiversity. Environ. Manag. 30, 492-507.

Claessen, D., Oss, C.v., Roos, A.M.d., Persson, L., 2002. The impact of size-dependent predation on population dynamics and individual life history. Ecology 83, 1660- 1675. Collins, A.L., Anderson, T.A., 1999. The role of food availability in regulating reproductive development in female golden perch. J. Fish Biol. 55, 94-104.

Cryer, M., Peirson, G., Townsend, C.R., 1986. Reciprocal interactions between roach, Rutilus rutilus, and zooplankton in a small lake: prey dynamics and fish growth and recruitment. Limnol. Oceanogr. 31, 1022-1038.

Cummins, K.W., Wuycheck, J.C., 1971. Caloric Equivalents for Investigations in Ecological Energetics. International Association of Theoretical and Applied Limnology, Communications, Stuttgart, Germany, p. 158

Cushing, D.H., 1996. Towards a Science of Recruitment in Fish Populations. Ecology Institute, Oldendorf/Luhe, p. 175.

DeLonay, A.J., Papoulias, D.M., Wildhaber, M.L., Annis, M.L., Bryan, J.L., Griffith, S.A., Holan, S.H., Tillitt, D.E., 2007. Use of behavioral and physiological indicators to evaluate Scaphirhynchus sturgeon spawning success. J. Appl. Ichthyol. 23, 428- 435.

DeLonay, A.J., Jacobson, R.B., Papoulias, D.M., Simpkins, D.G., Wildhaber, M.L., Reuter, J.M., Bonnot, T.W., Chojnacki, K.A., Korschgen, C.E., Mestl, G.E., Mac, M.J., 2009. Ecological requirements for pallid sturgeon reproduction and recruitment in the lower Missouri River: a research synthesis 2005-08. U.S. Geological Survey Scientific Investigations Report 2009-5201, p. 59. http://pubs.usgs. gov/sir/2009/5201/

Dudgeon, D., Arthington, A.H., Gessner, M.O., Kawabata, Z.-I., Knowler, D.J., Lévêque, C., Naiman, R.J., Prieur-Richard, A.-H., Soto, D., Stiassny, M.L.J., Sullivan, C.A., 2006. Freshwater biodiversity: importance, threats, status and conservation challenges. Biol. Rev. 81, 163-182.

Encina, L., Granado-Lorencio, C., 1997. Seasonal variations in the physiological status and energy content of somatic and reproductive tissues of chub. J. Fish Biol. 50, 511-522.

Flowers, H.J., Pine, W.E., Dutterer, A.C., Johnson, K.G., Ziewitz, J.W. Allen, M.S., Parauka, F.M., 2009. Spawning site selection and potential implications of modified flow regimes on viability of Gulf sturgeon populations. Trans. Am. Fish. Soc. 138, 1266-1284.

Frank, B.M., Baret, P.V., 2013. Simulating brown trout demogenetics in a river/ nursery brook system: the individual-based model DemGenTrout. Ecol. Model. 248, 184-202.

Gibson, R.N., 1994. Impact of habitat quality and quantity on the recruitment of juvenile flatfishes. Neth. J. Sea Res. 32, 191-206.

Gilliland, M.W., Becker, L., Cady, R., Gabig, J., Gilley, J., Kern, R.A., Larson, A., Nguyen, Q.M., Powers, W., Supalla, R., 1985. Simulation and decision-making: the Platte River basin in Nebraska. J. Am. Water Resour. Assoc. 21, 281-290.

Ginting, D., Zelt, R.B., Linard, J.I., 2008. Temporal differences in the hydrologic regime of the lower Platte River, Nebraska, 1895-2006. U.S. Geological Survey Scientific Investigations Report 2007-5267, p. 43. http://pubs.usgs.gov/sir/2007/5267/

Goodman, B.J., Guy, C.S., Camp, S.L., Gardner, W.M., Kappenman, K.M., Webb, M.A.H., 2013. Shovelnose sturgeon spawning in relation to varying discharge treatments in a Missouri River tributary. River Res. Appl. 29, 1004-1015.
Grimm, V., Railsback, S.F., 2012. Pattern-oriented modelling: a 'multiscope' for predictive systems ecology. Philos. Trans. R. Soc. B 367, 298-310.

Grimm, V., Berger, U., Bastiansen, F., Eliassen, S., Ginot, V., Giske, J., Goss-Custard, J., Grand, T., Heinz, S.K., Huse, G., Huth, A., Jepsen, J.U., Jorgensen, C., Mooij, W.M., Muller, B., Pe'er, G., Piou, C., Railsback, S.F., Robbins, A.M., Robbins, M.M., Rossmanith, E., Ruger, N., Strand, E., Souissi, S., Stillman, R.A., Vabo, R., Visser, U., DeAngelis, D.L., 2006. A standard protocol for describing individual-based and agent-based models. Ecol. Model. 198, 115-126.

Grimm, V., Berger, U., DeAngelis, D.L., Polhill, J.G., Giske, J., Railsback, S.F., 2010. The ODD protocol: a review and first update. Ecol. Model. 221, 2760-2768.

Hammen, J.J., 2015. Population characteristics and habitat associations of Shovelnose Sturgeon Scaphirhynchus platorynchus in the lower Platte River, Nebraska. Ph.D. Dissertation. University of Nebraska, Lincoln, Nebraska.

Hampe, A., Petit, R.J., 2005. Conserving biodiversity under climate change: the rear edge matters. Ecol. Lett. 8, 461-467.

Hart, D.D., Finelli, C.M., 1999. Physical-biological coupling in streams: the pervasive effects of flow on benthic organisms. Ann. Rev. Ecol. Syst. 30, 363-395.

Hay, C.H., Franti, T.G., Marx, D.B., Peters, E.J., Hesse, L.W., 2008. Macroinvertebrate drift density in relation to abiotic factors in the Missouri River. Hydrobiologia 598, 175-189.

Hayes, J.W., Stark, J.D., Shearer, K.A., 2000. Development and test of a whole-lifetime foraging and bioenergetics growth model for driftfeeding brown trout. Trans. Am. Fish. Soc. 129, 315-332.

Heino, M., Kaitala, V., 1999. Evolution of resource allocation between growth and reproduction in animals with indeterminate growth. J. Evol. Biol. 12, 423-429.

Hofpar, R.L., 1997. Biology of Shovelnose Sturgeon, Scaphirhynchus platorynchus, in the Lower Platte River. University of Nebraska, Lincoln, Nebraska, USA.

Houde, E.D., 1987. Fish early life dynamics and recruitment variability. Am. Fish. Soc. Symp. 2, 17-29.

Houde, E.D., 2009. Recruitment variability. In: Jakobsen, T., Fogarty, M.J., Megrey, B. A., Moksness, E. (Eds.), Fish Reproductive Biology: Implications for Assessment and Management. Wiley-Blackwell Scientific Publications, Chichester, UK, pp. 91-171.

Humphries, P., King, A., Koehn, J., 1999. Fish, flows and flood plains: links between freshwater fishes and their environment in the Murray-Darling river system, Australia. Environ. Biol. Fish. 56, 129-151.

Humphries, P., Richardson, A., Wilson, G., Ellison, T., 2013. River regulation and recruitment in a protracted-spawning riverine fish. Ecol. Appl. 23, 208-225.

Hutchings, J.A., 2002. Life histories of fish. In: Hart, P.J.B., Reynolds, J.D. (Eds.), Handbook of Fish and Fisheries, vol. 1. Blackwell, Oxford, UK, pp. 149-174.

Jacobson, R.B., Galat, D.L., 2008. Design of a naturalized flow regime - an example from the lower Missouri River, USA. Ecohydrology 1, 81-104.

Jager, H.I., Chandler, J.A., Lepla, K.B., Van Winkle, W., 2001. A theoretical study of river fragmentation by dams and its effects on white sturgeon populations. Environ. Biol. Fish. 60, 347-361.

Jager, H.I., 2001. Individual variation in life history characteristics can influence extinction risk. Ecol. Model. 144, 61-76.

Jonsson, B., Jonsson, N., Finstad, A.G., 2013. Effects of temperature and food quality on age and size at maturity in ectotherms: an experimental test with Atlantic salmon. J. Anim. Ecol. 82, 201-210.

King, A.J., Humphries, P., Lake, P.S., 2003. Fish recruitment on floodplains: the roles of patterns of flooding and life history characteristics. Can. J. Fish. Aquat. Sci. 60, 773-786.

Korschgen, Carl E., ed., 2007. Factors affecting the reproduction, recruitment, habitat, and population dynamics of pallid sturgeon and shovelnose sturgeon in the Missouri River. In: Korschgen, C.E. (Ed.), US Geological Survey Open-File Report 2007-1262, pp. 280. http://pubs.usgs.gov/of/2007/1262/

Lake, P.S., 2003. Ecological effects of perturbation by drought in flowing waters. Freshwater Biol. 48, 1161-1172.

Landguth, E.L., Muhlfeld, C.C., Waples, R.S., Jones, L., Lowe, W.H., Whited, D., Lucotch, J., Neville, H., Luikart, G., 2014. Combining demographic and genetic factors to assess population vulnerability in stream species. Ecol. Appl. 24, 1505-1524. 
Lucas, M.C., Marmulla, G., 2000. An assessment of anthropogenic activities on and rehabilitation of river fisheries: current state and future direction. In: Cowx, I.G. (Ed.), Management and Ecology of River Fisheries. Fishing News Books, Blackwell Science, Oxford, pp. 261-278.

Lytle, D.A., Poff, N.L., 2004. Adaptation to natural flow regimes. Trends Ecol. Evol. 19, 94-100.

Marschall, E.A., Mather, M.E., Parrish, D.L., Allison, G.W., McMenemy, J.R., 2011. Migration delays caused by anthropogenic barriers: modeling dams, temperature, and success of migrating salmon smolts. Ecol. Appl. 21, 3014-3031.

McBride, R.S., Somarakis, S., Fitzhugh, G.R., Albert, A., Yaragina, N.A., Wuenschel, M. J., Alonso-Fernández, A., Basilone, G., 2013. Energy acquisition and allocation to egg production in relation to fish reproductive strategies. Fish and Fisheries, doi: 10.1111/ faf.12043

Mion, J.B., Stein, R.A., Marschall, E.A., 1998. River discharge drives survival of larval walleye. Ecol. Appl. 8, 88-103.

Mueller, N.D., Gerber, J.S., Johnston, M., Ray, D.K., Ramankutty, N., Foley, J.A., 2012. Closing yield gaps through nutrient and water management. Nature 490, 254-257.

Nilsson, C., Berggren, K., 2000. Alterations of riparian ecosystems caused by river regulation. BioScience 50, 783-792. Nunn, A.D., Harvey, J.P., Britton, J.R., Frear, P.A., Cowx, I.G., 2007. Fish, climate and the Gulf Stream: the influence of abiotic factors on the recruitment success of cyprinid fishes in lowland rivers. Freshwater Biol. 52, 1576-1586.

Palmer, M.A., Reidy Liermann, C.A., Nilsson, C., Flörke, M., Alcamo, J., Lake, P.S., Bond, N., 2008. Climate change and the world's river basins: anticipating management options. Front. Ecol. Environ. 6, 81-89.

Papoulias, D.M., DeLonay, A.J., Annis, M.L., Wildhaber, M.L., Tillitt, D.E., 2011. Characterization of environmental cues for initiation of reproductive cycling and spawning in shovelnose sturgeon Scaphirhynchus platorynchus in the lower Missouri River, USA. J. Appl. Ichthyol. 27, 335-342.

Paragamian, V., Wakkinen, V., 2011. White sturgeon spawning and discharge augmentation. Fish. Manag. Ecol. 18, 314-321. Pegg, M.A., Pierce, C.L., Roy, A., 2003. Hydrological alteration along the Missouri River basin: a time series approach. Aquat. Sci. 65, 63-72.

Perry, G.L., Bond, N.R., 2009. Spatially explicit modeling of habitat dynamics and fish population persistence in an intermittent lowland stream. Ecol. Appl. 19, 731-746.

Peters, E.J., Parham, J.E., 2008. Ecology and management of sturgeon in the lower Platte River, Nebraska. Nebraska Technical Series. Nebraska Game and Parks Commission.

Peterson, J.T., Kwak, T.J., 1999. Modeling the effects of land use and climate change on riverine smallmouth bass. Ecol. Appl. 9, 1391-1404.

Phelps, Q.E., Tripp, S.J., Hintz, W.D., Garvey, J.E., Herzog, D.P., Ostendorf, D.E., Ridings, J.W., Crites, J.W., Hrabik, R.A., 2010. Water temperature and river stage influence mortality and abundance of naturally occurring Mississippi River Scaphirhynchus sturgeon. North Am. J. Fish. Manag. 30, 767-775.

Piou, C., Prévost, E., 2012. A demo-genetic individual-based model for Atlantic salmon populations: model structure, parameterization and sensitivity. Ecol. Model. 231, 37-52.

Poff, N.L., DeCino, R.D., Ward, J.V., 1991. Size-dependent drift responses of mayflies to experimental hydrologic variation: active predator avoidance or passive hydrodynamic displacement? Oecologia 88, 577-586.

Poff, N.L., Allan, J.D., Bain, M.B., Karr, J.R., Prestegaard, K.L., Richter, B.D., Sparks, R.E., Stromberg, J.C., 1997. The natural flow regime. BioScience 47, 769-784.

Railsback, S.F., Harvey, B.C., Jackson, S.K., Lamberson, R.H., 2009. InSTREAM: the Individual-based Stream Trout Research and Environmental Assessment Model, Gen Tech. Rep. PSW-GTR-218. U.S. Department of Agriculture, Forest Service, Pacific Southwest Research Station, Albany, CA, p. 254.

Reuter, J.M., Jacobson, R.B., Elliott, C.M., DeLonay, A.J., 2009. Assessment of lower Missouri River physical aquatic habitat and its use by adult sturgeon (genus Scaphirhynchus). U.S. Geological Survey Scientific Investigations Report 2009-5121, p. 81. http://pubs. usgs.gov/sir/2009/5121/.

Ricker, W.E., 1975. Computation and Interpretation of Biological Statistics for Fish Populations. Fisheries Research Board of Canada, Ottawa, Ontario, p. 382.
Rideout, R.M., Tomkiewicz, J., 2011. Skipped spawning in fishes: more common than you might think. Mar. Coast. Fish. 3, 176-189.

Rose, K.A., Smith, E.P., Gardner, R.H., Brenkert, A.L., Bartell, S.M., 1991. Parameter sensitivities, monte carlo filtering, and model forecasting under uncertainty. J. Forecast. 10, 117-133.

Rosenfeld, J.S., Ptolemy, R., Bradford, M.J., 2012. Modelling available habitat versus available energy flux: do PHABSIM applications that neglect prey abundance underestimate optimal flows for juvenile salmonids? Can. J. Fish. Aquat. Sci. 69, 1-15.

Rugg, M.L., 2013. Shovelnose Sturgeon Reproductive Ecology in the Lower Platte River, Nebraska. Masters Thesis. University of Nebraska, Lincoln, Nebraska.

Scarnecchia, D.L., Ryckman, L.F., Lim, Y., Power, G.J., Schmitz, B.J., Firehammer, J.A., 2007. Life history and the costs of reproduction in northern Great Plains paddlefish (Polyodon spathula) as a potential framework for other Acipenseri-form fishes. Rev. Fish Sci. 15, 211-263.

Scheffer, M., Baveco, J., DeAngelis, D., Rose, K., Van Nes, E., 1995. Super-individuals a simple solution for modelling large populations on an individual basis. Ecol. Model. 80, 161-170.

Schlosser, I.J., 1998. Fish recruitment, dispersal, and trophic interactions in a heterogeneous lotic environment. Oecologia 113, 260-268.

Schwarz, M.S., Lydick, C.D., Tillit, D.E., Papoulias, D.M., Gross, T.S., 2006. A health risk evaluation for pallid sturgeon (Scaphirhynchus albus) in the lower Platte River using shovelnose sturgeon (Scaphirhynchus platorynchus) as a surrogate. U.S. Fish and Wildlife Service, p. 1-119. http://www.fws.gov/contaminants/DisplayLibrary. cfm?ID=578F4983-EB8B-AD5B-CF080694808BCDAE\&Verify=0

Secor, D.H., 2008. Influence of skipped spawning and misspecified reproductive schedules on biological reference points in sustainable fisheries. Trans. Am. Fish. Soc. 137, 782-789.

Skjæraasen, J.E., Nash, R.D.M., Korsbrekke, K., Fonn, M., Nilsen, T., Kennedy, J., Nedreaas, K.H., Thorsen, A., Witthames, P.R., Geffen, A.J., Høie, H., Kjesbu, O.S., 2012. Frequent skipped spawning in the world's largest cod population. Proc. Natl. Acad. Sci. U. S. A. 109, 8995-8999.

Spindler, B.D., Chipps, S.R., Klumb, R.A., Graeb, B.D.S., Wimberly, M.C., 2012. Habitat and prey availability attributes associated with juvenile and early adult pallid sturgeon occurrence in the Missouri River, USA. Endang. Species Res. 16, 225- 234.

Stead, S.M., Houlihan, D.F., McLay, H.A., Johnstone, R., 1999. Food consumption and growth in maturing Atlantic salmon (Salmo salar). Can. J. Fish. Aquat. Sci. 56, 2019-2028.

Swigle, B.D., 2003. Movements and Habitat Use by Shovelnose and Pallid Sturgeon in the Lower Platte River, Nebraska. University of Nebraska, Lincoln.

Tripp, S.J., Phelps, Q.E., Colombo, R.E., Garvey, J.E., Burr, B.M., Herzog, D.P., Hrabik, R. A., 2009. Maturation and reproduction of shovelnose sturgeon in the Middle Mississippi River. North Am. J. Fish. Manag. 29, 730-738.

Whiles, M.R., Goldowitz, B.S., 2001. Hydrologic influences on insect emergence production from central Platte River wetlands. Ecol. Appl. 11, 1829-1842.

Whiles, M.R., Goldowitz, B.S., 2005. Macroinvertebrate communities in central Platte River wetlands: patterns across a hydrologic gradient. Wetlands 25, 462-472.

Wildhaber, M.L., DeLonay, A.J., Papoulias, D.M., Galat, D.L., Jacobson, R.B., Simpkins, D.G., Braaten, P.J., Korschgen, C.E., Mac, M.J., 2007. A conceptual life-history model for pallid and shovelnose sturgeon. U. S. Geol. Surv. Circ. 1315, p18.

Wildhaber, M.L., DeLonay, A.J., Papoulias, D.M., Galat, D.L., Jacobson, R.B., Simpkins, D.G., Braaten, P.J., Korschgen, C.E., Mac, M.J., 2011. Identifying structural elements needed for development of a predictive life- history model for pallid and shovelnose sturgeons. J. Appl. Ichthyol. 27, 462-469.

Wilson, M.A., Carpenter, S.R., 1999. Economic valuation of freshwater ecosystem services in the United States: 1971-1997. Ecol. Appl. 9, 772-783.

Winemiller, K.O., Rose, K.A., 1992. Patterns of life-history diversification in North American fishes: implications for population regulation. Can. J. Fish. Aquat. Sci. 49, 2196-2218. 


\section{Appendices. Supplementary data}

Daisuke Goto, Martin J. Hamel, Jeremy J. Hammen, Matthew L. Rugg, Mark A. Pegg, and Valery E. Forbes. Spatiotemporal variation in flow-dependent recruitment of longlived riverine fish: Model development and evaluation. Ecological Modelling. DOI: 10.1016/j.ecolmodel.2014.10.026.

Appendix A. Description of the SEIBM-1Dsns submodels................................

Appendix B. Sources and values of the sturgeon model parameters......................11

Appendix C. Derivation of environmental input data....................................14

Appendix D. Sources and values of the environment model parameters ..................15 


\section{Appendix A. Description of the SEIBM-1Dsns submodels}

The following sections describe submodels of a spatially explicit (1-dimensional) individualbased model for shovelnose sturgeon (Scaphirhynchu platorynchus) (SEIBM-1D SNS $_{\text {). Parameter }}$ values used for the model are provided in Appendix B. The model consists of one prey submodel and six sturgeon submodels with a total of 72 parameters as described below.

Drift invertebrate production. Drift prey biomass $\left(B_{\text {prey, }, i}\right)$ in grid cell $i$ on day $t$ is calculated as

$$
B_{\text {prey }, t, i}=B_{\text {prey }, t-1, i}+\text { Prod }_{\text {prey }, t, i}+M_{\text {prey }, t, i}-C_{\text {pred,t-1,i }}
$$

where $\operatorname{Prod}_{\text {prey,t,i}}$ is daily production $\left(\mathrm{g} \bullet \mathrm{m}^{-2} \bullet \mathrm{d}^{-1}\right), M_{\text {prey,t,i}}$ is net migration $\left(\mathrm{g}^{\bullet} \mathrm{d}^{-1}\right)$ from neighboring cells, and $C_{\text {pred,t-1,i }}$ is consumption by sturgeon $\left(\mathrm{g}^{\bullet} \mathrm{d}^{-1}\right) \cdot \operatorname{Prod}_{\text {prey,t,i}}$ is calculated daily using a logistic growth function (Rashleigh and Grossman, 2005) as

$$
\left.\operatorname{Prod}_{\text {prey }}=G R_{\text {prey }} \times 1+\operatorname{Var}_{\text {preyprod }} \sin \left(\frac{2 \pi D O Y}{365}\right) \times\left(1-\left(\frac{\text { Bio }_{\text {prey }}}{q_{\text {prod }} \times B \max _{\text {prey }}}\right)\right)\right) \times \text { Bio }_{\text {prey }}
$$

where $G R_{\text {prey }}$ is the growth rate $\left(\mathrm{d}^{-1}\right)$, Var preyprod is a term that accounts for variation in Prod prey $_{\text {, }}$ $q_{\text {prod }}$ is an indicator of discharge-dependent habitat quality (which ranges from 0-1), Bio prey is prey biomass in a grid cell $\left(\mathrm{g} \cdot \mathrm{m}^{-2}\right)$, and $B_{\text {max }}$ is the maximum biomass $\left(\mathrm{g} \bullet \mathrm{m}^{-2}\right)$ (Appendix B). $q_{\text {prod }}$ is a flow-dependent non-linear function calculated as $q_{\text {prod }}=1.01 \mathrm{e}^{-0.5(\text { Vmean }-0.603) / 0.249)^{\wedge} 2}$, where $V_{\text {mean }}$ is mean water velocity $\left(\mathrm{m} \bullet \mathrm{s}^{-1}\right) ; V_{\text {mean }}$ is calculated as $V_{\text {mean }}=$ Disc $/($ Width $\times$ Depth), where Disc, Width, and Depth are river discharge, width, and depth (Appendix C). $M_{\text {prey,t }}$ is calculated as

$$
M_{\text {prey }, t}=m_{\text {prod }} \times\left(B_{\text {prey }, t, i}-B_{\text {prey }, t-1, i}\right)
$$

where $m_{\text {prod }}$ is net migration rate $\left(\mathrm{d}^{-1}\right)$ (Appendix $\mathrm{B}$, Rashleigh and Grossman, 2005). Prey biomass in each grid cell is then distributed into five body length classes (1-3, 3-5, 5-7,7-9, and 9-11 mm). Relative density of each size class is calculated assuming the Poisson distribution with mean of $0.41 \mathrm{~mm}(=\sim 1 \mu \mathrm{g})$.

Embryonic and larval development. Embryonic development is evaluated by a cumulative fractional temperature-dependent function derived from data reported by Wang et al. (1985). Daily development of eggs $\left(D_{e g g}\right)$ is calculated as

$$
D_{e g g}=1 /\left(\alpha_{\text {egg }} \mathrm{e}^{-\beta e g g \text { Tave }} / 24\right)
$$

where $\alpha_{e g g}$ and $\beta_{\text {egg }}$ are constants (Appendix B), and $T_{a v e}$ is daily mean water temperature. Hatching occurs when $D_{\text {egg }} \geq 1$. We assume that hatched larvae use their yolk sac for $\sim 10$ days (at $17-18^{\circ} \mathrm{C}$, Wang et al., 1985) before exogenous feeding. Post-hatch yolk-sac larval development to the first exogenous feeding $\left(D_{\text {yalksac }}\right)$ is calculated with a temperature-dependent function derived from data reported by Wang et al. (1985) as

$$
D_{\text {yolksac }}=1 /\left(\left(\alpha_{y o l k s a c} \mathrm{e}^{-\beta y o l k s a c T a v e}-\alpha_{\text {egg }} \mathrm{e}^{-\beta e g g T a v e}\right) / 24\right)
$$


where $\alpha_{y o l k s a c}$ and $\beta_{\text {yolksac }}$ are constants (Appendix B). Exogenous feeding occurs when $D_{\text {yolksac }} \geq$ 1, after which we track foraging, growth, movement, and mortality for each $\mathrm{SI}_{\text {yoy. }}$

Foraging. Foraging is simulated with the functional response model by Beddington (1975) and DeAngelis et al. (1975), which is a function of encounter rate, handling time, prey selectivity, and prey and predator densities. This model incorporates both predator and prey densitydependent effects to reflect flow-dependent resource competition. Daily consumption rate of prey size class $i\left(C_{i}, \mathrm{~g} \bullet \mathrm{d}^{-1}\right)$ is calculated as

$$
C_{i}=\frac{W_{\text {preyi }} \times N_{\text {preyi }}}{1+\sum\left(E_{\text {preyi }} \times Q_{\text {preyi }} \times H T_{\text {preyi }}\right)+\sum\left(E_{\text {intra }} \times D_{\text {intra }}\right)}
$$

where $W_{\text {prey,i }}$ is body mass (mg, wet) of the $i$ th prey size class, $N_{\text {prey, }}$ is the realized number of the $i$ th prey size class consumed (number $\bullet \mathrm{s}^{-1}$ ), $E_{\text {prey, } \mathrm{i}}$ and $E_{\text {intra }}$ are the realized encounter rates for the $i$ th prey size class and other sturgeon individuals (number $\bullet \mathrm{s}^{-1}$, respectively), $Q_{\text {prey } i}$ is the probability of attacking the $i$ th prey size class, which is used to calculate $N_{\text {prey, },}, H T_{\text {prey }}$ is handling time (s) of the $i$ th prey size class, and $D_{\text {preyi }}$ and $D_{\text {intra }}$ are the density of $i$ th prey size class and sturgeon $\left(\mathrm{g} \cdot \mathrm{m}^{-2}\right)$ in a given cell, respectively.

To account for direct flow-dependence in foraging by shovelnose sturgeon (Modde and Schmulbach, 1977; Seibert et al., 2011), we use the drift foraging model by Guensch et al. (2001) to calculate the realized encounter rate $\left(E_{\text {prey,i }}\right.$ and $\left.E_{\text {intra }}\right)$; drift-feeding sturgeon are assumed to encounter and capture prey within an area defined by fish swimming speed and water velocity. $E_{\text {prey, }}$ and $E_{\text {intra }}$ are calculated by a randomly drawn number from a Poisson distribution with potential encounter rate $\left(E R_{\text {prey } i}\right.$ or intra number $\left.\bullet \mathrm{s}^{-1}\right)$ as the number of trials, calculated as

$$
E R_{\text {prey } i \text { or intra }}=V_{\max } \times M C A_{\text {prey } i \text { or intra }} \times D_{\text {prey } i \text { or intra }}
$$

where $V_{\text {max }}$ is the maximum sustainable swimming speed of sturgeon $\left(\mathrm{m}^{\bullet} \mathrm{s}^{-1}\right)$, and $M C A_{\text {prey }} i$ or intra is the maximal capture (or competition for $M C A_{\text {intra }}$ ) area $\left(\mathrm{m}^{2}\right) . V_{\max }$ is calculated by empirically derived functions of temperature and fish length; $V_{\max }$ increases with increasing temperature and fish length. $M C A_{i}$ is calculated as

$$
M C A_{i}=\frac{\Delta \Theta}{2} \times M C D^{2}
$$

where $\Delta \Theta$ is an incremental angle perpendicular to the flow vector ( $M C A$ is divided into 10 equal segments, Guensch et al., 2001), and $M C D_{i}$ is the maximal capture (or competition) distance (m). $M C D_{i}$ is a function of fish swimming speed and water velocity and is calculated as

$$
M C D_{i}=\frac{R D_{i}^{2} \times\left(V_{\max }^{2}-V_{\text {mean }}^{2}\right)}{\left.V_{\text {bottom }}^{2}+V_{\max }^{2}-V_{\text {mean }}^{2}\right)}
$$

where $R D_{i}$ is the reactive distance to the $i$ th prey size class (m) and $V_{\text {bottom }}$ is bottom water velocity $\left(\mathrm{m} \cdot \mathrm{s}^{-1}\right)$. $V_{\text {bottom }}$ is calculated using a function of $V_{\text {mean }}$ empirically derived for the LPR using data reported by Peters and Parham (2008); $V_{\text {bottom }}=0.1176+0.4031 V_{\text {mean }}$. When water velocity is greater than their swimming speed, sturgeon stop foraging. $R D_{i}$ is calculated by an empirically derived function of prey and sturgeon lengths as 


$$
R D_{i}=\alpha_{R D}\left(L_{\text {prey }} / 10\right) \times\left(1-e^{-\beta_{R D} L_{f s h}}\right)
$$

where $\alpha_{R D}$ and $\beta_{R D}$ are constants (Appendix B), $L_{\text {prey }}$ is prey length (mm) and $L_{f i s h}$ is sturgeon length (mm). In the Foraging submodel, exact body length of drift prey is randomly assigned using a uniform distribution (between minimum and maximum of each size class) each day. The attack probability $\left(Q_{\text {preyi }}\right)$ is then calculated as a function of selectivity and prey density as

$$
Q_{\text {preyi }}=\frac{C \alpha_{i} \times D_{\text {preyi }}}{\sum C \alpha_{i} \times D_{\text {preyi }}}
$$

where $C \alpha_{i}$ is prey selectivity based on Chesson's alpha for the prey size class $i . D_{\text {preyi }}$ is calculated by dividing total biomass by individual mass (i.e., $D_{\text {preyi }}=B_{\text {preyi }} / W_{\text {preyi }}$, where $W_{\text {prey } i}$ is the body mass of the $i$ th prey size class (g wet), calculated using an empirically derived function as $W_{\text {prey }}{ }=0.0018 L_{\text {prey }}{ }^{2.62} / 0.145 / 1000$ (Benke et al., 1999). $C \alpha_{i}$ is calculated by a prey size-dependent function as

$$
\left.C \alpha_{i}=\mid \alpha_{C \alpha}-\beta_{C \alpha}\left(L_{p r e y} / L_{f i s h}\right)\right) \mid
$$

where $\alpha_{C \alpha}$ and $\beta_{C \alpha}$ are constant (Rose et al. 1997). Handling time $\left(H T_{p r e y}, \mathrm{~s}\right)$ for drift-feeding sturgeon is assumed to be 1.0.

The daily foraging rate is limited by a temperature-dependent maximum daily consumption rate $\left(C_{\max }, \mathrm{g} \cdot \mathrm{d}^{-1}\right)$ and is calculated as

$$
C_{\text {max }}=\alpha_{c \max } W_{\text {fish }}{ }^{\beta c \max } \times f T_{\text {cmax }}
$$

where $\alpha_{c \max }$ and $\beta_{c \max }$ are constants (Appendix B), $W_{f i s h}$ is total mass of sturgeon (g wet), and $f T_{\text {cmax }}$ is a temperature-dependent function, calculated as

$$
f T_{c m a x}=\left(\alpha_{T c}-\beta_{T c} T_{a v e}\right)^{\gamma \mathrm{Tc}} \times \mathrm{e}^{(\delta T c T a v e-\varepsilon T c)}
$$

where $\alpha_{T c}, \beta_{T c}, \gamma_{T c}, \delta_{T c}$, and $\varepsilon_{T c}$ are constants (Appendix B).

Growth. Growth is simulated by the bioenergetics model (Hanson et al., 1997) modified to incorporate energy allocation to storage and gonad tissues (Bevelhimer, 2002; Sibly et al., 2013); The standard bioenergetics model assumes that energy available for growth is a function of energy consumed less energy lost due to metabolism as

$$
G=C-R-F-U-S D A
$$

where $G$ is growth, $C$ is consumption, $R$ is respiration, $F$ is egestion, $U$ is excretion, and $S D A$ is specific dynamic action. All units are in $\mathrm{g} \bullet \mathrm{g}^{-1} \bullet$ day $^{-1} . C$ is derived from the Foraging submodel. $R$ is calculated as

$$
R=\alpha_{R} W_{f i s h}^{\beta R} \times f T_{R} \times A C T \times O F
$$


where $\alpha_{R}$ and $\beta_{R}$ are constants, $f T_{R}$ is a temperature-dependent function, $A C T$ is an activity multiplier, and $O F$ is an oxycalorific factor (Appendix B). $f T_{R}$ is calculated as

$$
f T_{R}=e^{\alpha_{T R} T_{\text {ave }}}
$$

where $\alpha_{\mathrm{TR}}$ is a constant (Appendix B).

$F$ is calculated as

$$
F=\alpha_{F} C
$$

where $\alpha_{F}$ is a constant (Appendix B). $U$ is calculated as

$$
U=\alpha_{U}(C-F)
$$

where $\alpha_{U}$ is a constant (Appendix B). SDA is calculated as

$$
S D A=\alpha_{S D A}(C-F)
$$

where $\alpha_{S D A}$ is a constant (Appendix B).

In this model, we assume that once assimilated, energy is allocated to storage (reversible, $W_{\text {str }}$ ) and structural (irreversible, $W_{\text {strc }}$ ) tissues (Gurney et al., 2003; Höök et al., 2008). To calculate growth, grams of prey consumed from the Foraging submodel are first converted to joules (ED prey, Appendix B). For post-settlement larvae and juveniles, when $W_{\text {str }}$ is less than optimal storage mass $\left(W_{\text {stropt }}\right)$, surplus net energy is allocated to storage tissue first until $W_{\text {stropt }}$ is reached. $W_{\text {stropt }}$ is calculated as

$$
W_{\text {stropt }}=W_{\text {fish }} \times \rho_{\text {opt }}
$$

where $\rho_{\text {opt }}$ is the proportion of optimal storage mass relative to total mass. $\rho_{\text {opt }}$ is calculated using a length-dependent function as

$$
\begin{gathered}
\rho_{\text {opt }}=\alpha_{\rho} \operatorname{In}\left(L_{f i s h}\right)+\beta_{\rho}, \text { when } \rho_{\text {opt }}>0.2 \\
\text { otherwise, } \rho_{\text {opt }}=0.2
\end{gathered}
$$

where $\alpha_{\rho}$ and $\beta_{\rho}$ are constants (Appendix B, Höök et al., 2008). When $W_{\text {str }}$ is greater than $W_{\text {stropt }}$, the surplus energy is allocated to both storage and structural mass such that $\rho_{\text {opt }}$ is maintained as

$$
\begin{gathered}
W_{s t r}=\rho_{o p t} \times \frac{E D_{S t r}}{E D_{S t r}+E D_{S t r c}} \\
W_{s t r c}=\left(1-\rho_{o p t}\right) \times \frac{E D_{S t r c}}{E D_{S t r}+E D_{S t r c}}
\end{gathered}
$$

where $E D_{\text {str }}$ and $E D_{\text {strc }}$ are energy density of storage and structural tissues (Appendix B).

Growth in length is then calculated using length-mass functions, which are modified such that length increases only when structural mass increases as 


$$
L_{f i s h}=\alpha_{\text {grow }} W_{\text {strc }}^{\text {Bgrow }}
$$

where $\alpha_{\text {grow }}$ and $\beta_{\text {grow }}$ are constants (Appendix B). When the assimilated energy is less than the energy expended through metabolism (negative net energy), mass is lost only from the storage tissue, while structural mass and length remain the same.

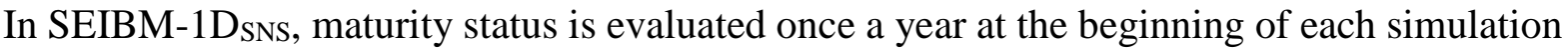
year. Probability of maturation $\left(P_{\text {mature }}\right)$ is calculated by an empirically derived function of body length using data reported by Tripp et al. (2009) as

$$
P_{\text {mature }}=\frac{1}{1+\left(\frac{L_{\text {fish }}}{\alpha_{\text {Pmature }}}\right)^{-\beta_{\text {Pmature }}}}
$$

where $\alpha_{\text {Pmature }}$ and $\beta_{\text {Pmature }}$ are constants (Appendix B).

For reproductive adults, energy is also allocated to gonad development. We assume that mature sturgeon in the reproductive cycle gradually allocate energy to gonad tissue between spawning events. The energy allocation to gonadal development follows the formulation by Van Winkle et al. (1997). Adults initiate the annual reproductive cycle only when their physiological condition $(K S)$ is above the threshold value for reproduction $\left(K S_{\text {rep }}\right)$. In SEIBM-1D $\mathrm{D}_{\text {sNS }}$, we calculate $K S$ using relative storage mass (as $K S=W_{\text {stor }} / W_{\text {optstor }}$ ). Adults who do not meet the minimum physiological condition do not enter the annual reproductive cycle and allocate energy only to structural and storage tissues.

The amount of daily energy allocated to $E_{\text {gonad }}\left(\gamma_{\text {gonad }}, \mathrm{J} \cdot \mathrm{d}^{-1}\right)$ by healthy $(K S \geq 1.0)$ adults is a function of expected gonad energy content on the spawning day, the minimal spawning interval (1 year for males and 3 years for females), and the earliest expected spawning day (Appendix B). The expected gonad energy content on the spawning day is calculated by an allometric function as

$$
E_{\text {gonad }}=\alpha_{g} W_{\text {struc }}^{\beta g}
$$

where $\alpha_{g}$ and $\beta_{g}$ are constants (Appendix B).

While the earliest expected spawning day is assumed to occur in late March (when daylight hours $>12 \mathrm{~h}$ ), the realized spawning day is determined by discharge, temperature, and gonadosomatic index or GSI (see Spawning submodel). $\gamma_{\text {gonad }}$ is further adjusted when the physiological condition is below the threshold as

$$
\gamma_{\text {gonad }}=\left\{\begin{array}{l}
\gamma_{\text {gonad }}, \text { when } K S \geq K S_{\text {norm }} \\
\gamma_{\text {gonad }} \times\left(1-\mathrm{e}^{-\delta g(K S-K S \text { spawn })}\right), \text { when } K S<K S_{\text {norm }} \\
0, \text { when } K S<K S_{\text {spawn }}
\end{array}\right.
$$

where $K S_{\text {norm }}$ is the normal physiological condition, $\delta_{g}$ is a constant, and $K S_{s p w n}$ is the minimum physiological condition to remain in the reproductive cycle (Appendix B).

Spawning. Spawning is a stochastic event and occurs only when the following ecological and physiological conditions are concurrently met: (1) water temperature (Gilliland et al., 1985); (2) minimum discharge rate; and (3) the minimal GSI (Pelletier and Mahévas, 2005) (Appendix B). 
These conditions determine the spawning day, as well as the number of spawning adults producing viable gametes. Fecundity $\left(N_{e g g}\right)$ is calculated by dividing energy content of gonad by that of an egg (i.e., $N_{\text {egg }}=E_{\text {gonad }} / E_{\text {egg }}$, where $E_{\text {gonad }}$ is the energy content $(\mathrm{J})$ of the gonad on the spawning day, and $E_{\text {egg }}$ is the energy content of a single egg $\left(\mathrm{J} \bullet \mathrm{egg}^{-1}\right.$, Appendix B). We assume that size and energy content of eggs are uniform and constant. After spawning, these individuals lose all gonad mass, and their $K S$ and total mass are updated. Spawning adults do not re-enter the reproductive cycle until $K S$ meets the threshold.

Movement. In the SEIBM-1D $\mathrm{D}_{\mathrm{SNS}}$, fish movement is tracked in the longitudinal direction only. The movement consists of two components; orientation (upstream and downstream) and distance (m). The movement of eggs and pre-settlement larvae is determined only by water velocity. The movement of post-settlement larvae, juveniles, and adults is determined by habitat quality based on discharge and drift prey biomass.

Shovelnose sturgeon are generally sedentary (mean daily movement rates < $350 \mathrm{~m}$, Hurley et al., 1987; Peters and Parham, 2008). In the SEIBM-1Dsns, we assume that the maximum distance that fish can travel daily is limited to be within three (above or below the current grid cell) neighboring cells (or $3.0 \mathrm{~km}$ ). We assume that during the day, fish swim within this limited area and explore these neighboring grid cells before they 'settle' to a new cell. Individuals that are located within the upper or lower two boundary cells (1-2 or 161-162 rkm) can move out of the model LPR system (the probability of these individuals to emigrate is set to 0.01 ), but the movement into tributaries of the LPR or the mainstem Missouri River is not evaluated; the fish emigrated from the LPR system are treated as being 'lost' from the population.

The direction of a fish's movement is determined by its responses to habitat quality of the current and neighboring (one above and one below) cells. The overall habitat quality of the cells is calculated as

$$
E N V_{V i}=\operatorname{Disc}_{F i}{ }^{\alpha M} \times \text { Connect }_{F i}^{\beta M} \times \operatorname{Prey}_{F i}{ }^{\gamma M} \times R U
$$

where Disc $_{F i}$, Connect $F i$, and Prey ${ }_{F i}$ are habitat quality indices based on habitat availability, river connectivity, and drift prey density (respectively) in the grid cell $i, R U$ is a random variate drawn from a uniform distribution for inherent uncertainty in a fish's ability to assess habitat quality, $\alpha_{M}, \beta_{M}$, and $\gamma_{M}$ are weights for each habitat index. In the SEIBM-1DSNS, the weights are equally assigned for discharge and drift prey density. Fish move (or stay in the current cell) in the direction (upstream or downstream) with highest overall habitat quality.

Normalized habitat-quality indices (which vary between 0 and 1) of the cells are determined as follows: Prey $y_{F i}$ is based on a cumulative prey selectivity-adjusted density, which is a function of prey density, prey size, and fish size from the Foraging submodel (i.e., $Q_{\text {preyi }}$ ); Disc ${ }_{F i}$ and Connect $_{F i}$ are empirically derived from discharge-dependent habitat suitability and river connectivity models developed for the LPR population of shovelnose sturgeon (Peters and Parham, 2008) as

$$
\begin{gathered}
\left.\left.\left.\operatorname{Disc}_{F i}=\left(\alpha_{\text {HSIdis }} e^{-e^{-(\operatorname{Disc}-\log (\log (2))}}-\beta_{\text {HSIdis }}\right) / \delta_{H S I d i s}\right)\right)\right) / \alpha_{H S I d i s} \\
\text { Connect }_{F i}=\alpha_{\text {Connect }} /\left(1+e^{-(\text {Disc- } \beta \text { Connect }) / \gamma \text { Connect }}\right)
\end{gathered}
$$


where $\alpha_{\text {HSIdis }}, \beta_{\text {HSIdis }}, \delta_{\text {HSIdis }} \alpha_{\text {Connect }}, \beta_{\text {Connect }}$, and $\delta_{\text {Connect }}$ are constants (Appendix B). Furthermore, we assume that sturgeon avoid cells with water velocity greater than their critical swimming speed ( $V_{\text {max; }}$ see Foraging submodel); Disc ${ }_{F i}$ of those cells is set to 0 .

Once movement orientation is determined, the new realized location is calculated using fish swimming speed and water velocity as

$$
\operatorname{Lon}_{t}=\operatorname{Lon}_{t-1}+\left(v_{z}+w_{z}\right) \times t_{\text {move }}
$$

where $\operatorname{Lon}_{t}$ and $\operatorname{Lon}_{t-1}$ are spatial locations of fish at $t$ and $t-1(\mathrm{rkm}), v_{\mathrm{z}}$ is sturgeon swimming speed (when sturgeon move upstream, $\left.v_{\mathrm{z}}=-v_{\mathrm{z}}\right), w_{\mathrm{z}}$ is water velocity $\left(\mathrm{m} \cdot \mathrm{s}^{-1}\right)$, and $t_{\text {move }}$ is time that sturgeon are active $(\mathrm{h})$.

Mortality. In SEIBM-1DSNS, mortality is caused by high temperature (eggs and yolk-sac larvae), predation (eggs, larvae, and juveniles), starvation, and fishing (age 3+). We assume that a constant proportion $\left(M_{t h r m}\right)$ of eggs and yolk-sac larvae die when water temperature rises above $24{ }^{\circ} \mathrm{C}$ (Quist et al., 2004); $M_{\text {thrm }}$ is set to 0.8 . For predation, starvation, and fishing mortality, realized mortality is calculated as a stochastic event. The probabilities of predation and fishing mortality ( $M_{\text {pred }}$ and $M_{\text {angl }}$, respectively) are calculated as

$$
M_{\text {pred } \text { or } \text { angl }}=1-\mathrm{e}^{- \text {Zpred } \text { or Angl }}
$$

where $Z_{\text {pred }}$ is a size-dependent daily instantaneous mortality rate, calculated as

$$
Z_{\text {pred }}=\alpha \text { Zpred } e^{-\beta_{\text {zpred }} L_{\text {fsish }}}
$$

where $\alpha_{Z p r e d}$ and $\beta_{\text {Zpred }}$ are constants (Appendix B). We assume that predation mortality declines as turbidity increases, the turbidity effect $\left(P_{T r b}\right)$ is modeled using a logistic function based on data reported by Gadomski and Parsley (2005) as

$$
P_{T r b}=\alpha_{T r b} /\left(1+\mathrm{e}^{-(\operatorname{Tr} b-298.6103) /-\beta T r b}\right)
$$

where $T r b$ is turbidity (NTB), and $\alpha_{T r b}$ and $\beta_{T r b}$ are parameters (Appendix B). Fishing mortality rate $\left(Z_{\text {angl }}\right)$ is estimated from annual harvest rates in the LPR (Peters and Parham, 2008).

The probability of starvation mortality $\left(M_{\text {starv }}\right)$ is storage weight-dependent and calculated as

$$
M_{\text {starv }}=\alpha_{\mathrm{S}}+\beta_{S} \rho_{\text {opt }}
$$

where $\alpha_{S}$ and $\beta_{S}$ are constants (Appendix B).

Realized mortality of eggs and larvae is calculated by drawing a random number from the binomial distribution with $M_{\text {pred }}$ or $M_{\text {starv }}$ as the probability and the number of individuals represented by each $\mathrm{SI}_{\text {yoy }}$ as the number of trials. For age 1+ sturgeon, each individual dies when a random number drawn from a uniform distribution is below either $M_{\text {starv }}$ or $M_{\text {angl }}$. Starvation mortality is evaluated only when a proportion of storage mass relative to total mass drops below the threshold ( $\rho_{\text {opt }}$, Appendix B).

\section{References}


Beddington, J., 1975. Mutual interference between parasites or predators and its effect on searching efficiency. Journal of Animal Ecology, 331-340.

Benke, A.C., Huryn, A.D., Smock, L.A., Wallace, J.B., 1999. Length-mass relationships for freshwater macroinvertebrates in North America with particular reference to the southeastern United States. Journal of the North American Benthological Society 18, 308-343.

Bevelhimer, M.S., 2002. A bioenergetics model for white sturgeon Acipenser transmontanus: assessing differences in growth and reproduction among Snake River reaches. Journal of Applied Ichthyology 18, 550-556.

DeAngelis, D., Goldstein, R., O'neill, R., 1975. A model for tropic interaction. Ecology, 881892.

Gadomski, D.M., Parsley, M.J., 2005. Effects of turbidity, light level, and cover on predation of white sturgeon larvae by prickly sculpins. Transactions of the American Fisheries Society 134, 369-374.

Gilliland, M.W., Becker, L., Cady, R., Gabig, J., Gilley, J., Kern, R.A., Larson, A., Nguyen, Q.M., Powers, W., Supalla, R., 1985. Simulation and decisionmaking: the Platte River basin in Nebraska. JAWRA Journal of the American Water Resources Association 21, 281-290.

Guensch, G., Hardy, T., Addley, R., 2001. Examining feeding strategies and position choice of drift-feeding salmonids using an individual-based, mechanistic foraging model. Canadian Journal of Fisheries and Aquatic Sciences 58, 446-457.

Gurney, W.S.C., Jones, W., Veitch, A.R., Nisbet, R.M., 2003. Resource allocation, hyperphagia, and compensatory growth in juveniles. Ecology 84, 2777-2787.

Hanson, P.C., Johnson, T.B., Schindler, D.E., Kitchell, J.F., 1997. Fish bioenergetics 3.0. University of Wisconsin Sea Grant Institute, Madison, WI.

Höök, T.O., Rutherford, E.S., Croley, T.E., Mason, D.M., Madenjian, C.P., 2008. Annual variation in habitat-specific recruitment success: implications from an individual-based model of Lake Michigan alewife (Alosa pseudoharengus). Canadian Journal of Fisheries and Aquatic Sciences 65, 1402-1412.

Hurley, S.T., Hubert, W.A., Nickum, J.G., 1987. Habitats and movements of shovelnose sturgeons in the upper Mississippi River. Transactions of the American Fisheries Society $116,655-662$.

Modde, T., Schmulbach, J.C., 1977. Food and feeding behavior of the shovelnose sturgeon, Scaphirhynchus platorynchus, in the unchannelized Missouri River, South Dakota.

Transactions of the American Fisheries Society 106, 602-608.

Pelletier, D., Mahévas, S., 2005. Spatially explicit fisheries simulation models for policy evaluation. Fish and Fisheries 6, 307-349.

Peters, E.J., Parham, J.E., 2008. Ecology and management of sturgeon in the lower Platte River, Nebraska. Nebraska Technical Series.

Quist, M., Boelter, A., Lovato, J., Korfanta, N., Bergman, H., Latka, D., Korschgen, C., Galat, D., Krentz, S., Oetker, M., 2004. Research and assessment needs for pallid sturgeon recovery in the Missouri River. Final Report to the US Geological Survey. US Army Corps of Engineers, US Fish and Wildlife Service, and US Environmental Protection Agency. William D. Ruckelshaus Institute of Environment and Natural Resources, University of Wyoming, Laramie.

Rashleigh, B., Grossman, G.D., 2005. An individual-based simulation model for mottled sculpin (Cottus bairdi) in a southern Appalachian stream. Ecological modelling 187, 247-258. 
Seibert, J.R., Phelps, Q.E., Tripp, S.J., Garvey, J.E., 2011. Seasonal diet composition of adult Shovelnose Sturgeon in the middle Mississippi River. The American Midland Naturalist 165, 355-363.

Sibly, R.M., Grimm, V., Martin, B.T., Johnston, A.S.A., Kułakowska, K., Topping, C.J., Calow, P., Nabe-Nielsen, J., Thorbek, P., DeAngelis, D.L., 2013. Representing the acquisition and use of energy by individuals in agent-based models of animal populations. Methods in Ecology and Evolution 4, 151-161.

Tripp, S.J., Phelps, Q.E., Colombo, R.E., Garvey, J.E., Burr, B.M., Herzog, D.P., Hrabik, R.A., 2009. Maturation and reproduction of shovelnose sturgeon in the middle Mississippi River. North American Journal of Fisheries Management 29, 730-738.

Van Winkle, W., Rose, K.A., Shuter, B.J., Jager, H.I., Holcomb, B.D., 1997. Effects of climatic temperature change on growth, survival, and reproduction of rainbow trout: predictions from a simulation model. Canadian Journal of Fisheries and Aquatic Sciences 54, 2526-2542.

Wang, Y.L., Binkowski, F.P., Doroshov, S.I., 1985. Effect of temperature on early development of white and lake sturgeon, Acipenser transmontanus and A. fulvescens. Environmental Biology of Fishes 14, 43-50. 
Appendix B. Sources and values of the sturgeon model parameters.

\begin{tabular}{|c|c|c|c|c|c|}
\hline Parameter & Value & Units & Description & Equation & Source \\
\hline \multicolumn{6}{|c|}{ Initialization } \\
\hline$L_{\text {fish } \infty}$ & $770.78,811.52$ & $\mathrm{~mm}$ & Asymptotic average length (male and female, respectively) & 1 & Tripp et al. 2009 \\
\hline$K_{L}$ & $0.14,0.11$ & year-1 $^{-1}$ & Brody growth rate coefficient (male and female, respectively) & 1 & Tripp et al. 2009 \\
\hline$t_{0}$ & $-1.13,-1.99$ & unitless & von Bertalanffy parameter (male and female, respectively) & 1 & Tripp et al. 2009 \\
\hline \multicolumn{6}{|c|}{ Embryonic development } \\
\hline$\alpha_{\text {egg }}$ & 1185.03 & unitless & Coefficient of the fractional development of an embryo & $\mathrm{A} 2$ & Wang et al. 1985 \\
\hline$\beta_{\text {egg }}$ & -0.127 & unitless & Exponent of the fractional development of an embryo & $\mathrm{A} 2$ & Wang et al. 1985 \\
\hline \multicolumn{6}{|c|}{ Larval development } \\
\hline$\alpha_{y o l k s a c}$ & 1535.62 & unitless & Coefficient of the fractional development of a yolk-sac larva & A3 & Wang et al. 1985 \\
\hline$\beta_{\text {yolksac }}$ & -0.071 & unitless & Exponent of the fractional development of a yolk-sac larva & A3 & Wang et al. 1985 \\
\hline \multicolumn{6}{|c|}{ Foraging } \\
\hline$\alpha_{C \alpha}, \beta_{C \alpha}$ & $0.5,1.75$ & unitless & Parameters in the Chesson's $\alpha$ & A4f & Rose et al. 1996 \\
\hline$\alpha_{R D}$ & 0.12 & unitless & Coefficient of the reactive distance function & A4d & Bevelhimer 2002 \\
\hline$\beta_{R D}$ & 0.2 & unitless & Exponent of the reactive distance function & A $4 d$ & Bevelhimer 2002 \\
\hline$\alpha_{c \max }$ & 0.18 & unitless & Intercept of the maximum daily consumption function & A5 & Bevelhimer 2002 \\
\hline$\beta_{\text {cmax }}$ & 0.75 & unitless & Slope of the maximum daily consumption function & A5 & Bevelhimer 2002 \\
\hline$\alpha_{T c}, \beta_{T c}$ & $3.81,0.125$ & unitless & Coefficients in the temperature function & A5a & Bevelhimer 2002 \\
\hline$\gamma_{T c}, \delta_{T c}, \varepsilon_{T c}$ & $1.57,0.19625,3.925$ & unitless & Exponents in the temperature function & A5a & Bevelhimer 2002 \\
\hline \multicolumn{6}{|c|}{ Metabolism } \\
\hline$\alpha_{R}$ & 7.13 & unitless & Intercept of the allomateric mass function & A6a & Bevelhimer 2002 \\
\hline$\beta_{R}$ & 0.78 & unitless & Slope of the allometric mass function & A6a & Bevelhimer 2002 \\
\hline$A C T$ & $3.8,3.5,2.2$ & unitless & Activity multiplier (larva, juvenile, and adult, respectively) & A6a & Calibration \\
\hline$O F$ & 13560 & $\mathrm{~J} \cdot \mathrm{g}^{-1} \mathrm{O}_{2}$ & Oxycalorific conversion factor & A6a & Hanson et al. 1997 \\
\hline$\alpha_{\mathrm{TR}}$ & 0.0693 & unitless & Exponent of the temperature function & A6b & Bevelhimer 2002 \\
\hline$\alpha_{F}$ & 0.15 & unitless & Proportion of consumed energy allocated to egestion & A6c & Bevelhimer 2002 \\
\hline$\alpha_{U}$ & 0.05 & unitless & $\begin{array}{l}\text { Proportion of consumed energy allocated to excretion } \\
\text { Proportion of consumed energy allocated to specific dynamic }\end{array}$ & A6d & Bevelhimer 2002 \\
\hline$\alpha_{S D A}$ & 0.12 & unitless & action & A6e & Bevelhimer 2002 \\
\hline \multicolumn{6}{|c|}{ Growth } \\
\hline$\alpha_{\rho}$ & 0.12768 & unitless & Slope of the optimal $\rho$ function & A7a & $\begin{array}{l}\text { Estimated from Shuman et al. } \\
\qquad 2007 \text { data } \\
\text { Estimated from Shuman et al. }\end{array}$ \\
\hline$\beta_{\rho}$ & 0.02 & unitless & Intercept of the optimal $\rho$ function & A7a & 2007 data \\
\hline$E D_{\text {str }}$ & 8457 & $\mathrm{~J} \cdot \mathrm{g}^{-1}$ & Energy density of storage tissue & $\mathrm{A} 7 \mathrm{~b}, \mathrm{~A} 7 \mathrm{c}$ & Wang et al. 1987 \\
\hline$E D_{\text {strc }}$ & 4396 & $\mathrm{~J} \cdot \mathrm{g}^{-1}$ & Energy density of structural tissue & $\mathrm{A} 7 \mathrm{~b}, \mathrm{~A} 7 \mathrm{c}$ & USDA 2001 \\
\hline$\alpha_{\text {grow }}$ & $\begin{array}{c}0.000000366 \\
0.00000031\end{array}$ & unitless & $\begin{array}{l}\text { Coefficient of the structural mass-length function (YOY and } \\
\text { YAO, respectively) }\end{array}$ & A8 & $\begin{array}{l}\text { Estimated from Shuman et al. } \\
\qquad 2007 \text { data }\end{array}$ \\
\hline
\end{tabular}


Goto et al. Appendices 12

\begin{tabular}{|c|c|c|c|c|c|}
\hline & \multirow{2}{*}{$\begin{array}{l}\text { Estımated from Shuman et al. } \\
2007 \text { data }\end{array}$} \\
\hline$\beta_{\text {grow }}$ & $2.73,3.39$ & unitless & YAO, respectively) & A8 & \\
\hline$E D_{\text {prey }}$ & 3138 & $\mathrm{~J} \cdot \mathrm{g}^{-1}$ & Energy density of drift prey & & Lantry and Stewart 1993 \\
\hline$\alpha_{\text {Pmature }}$ & $0.9236,1.0711$ & unitless & \multirow{2}{*}{$\begin{array}{c}\text { female, respectively) } \\
\text { Exponent of the allometric maturation function (male and } \\
\text { female, respectively) } \\
\text { Intercept of the allometric maturation function (male and }\end{array}$} & A9 & Tripp et al. 2009 \\
\hline$\beta_{\text {Pmature }}$ & $570.6,674.7$ & unitless & & A9 & Tripp et al. 2009 \\
\hline$\gamma_{\text {Pmature }}$ & $-21.4,-15.88$ & unitless & \multirow{3}{*}{$\begin{array}{l}\text { female, respectively) } \\
\text { Intercept of the allometric gonad function (female and male, } \\
\text { respectively) } \\
\text { Slope of the allometric gonad function (female and male, } \\
\text { respectively) }\end{array}$} & A9 & Tripp et al. 2009 \\
\hline$\alpha_{g}$ & $0.22,0.03$ & unitless & & A10 & Calibration \\
\hline$\beta_{g}$ & $1.05,1.29$ & unitless & & A10 & Calibration \\
\hline$\delta_{g}$ & 18.5 & unitless & \multirow{4}{*}{$\begin{array}{c}\text { Exponent of the gonad energy allocation function } \\
\text { Normal physiological condition } \\
\text { Minimum physiological condition to enter in the reproductive } \\
\text { cycle } \\
\text { Minimum physiological condition to remain in the } \\
\text { reproductive cycle }\end{array}$} & A11 & Calibration \\
\hline$K S_{\text {norm }}^{\circ}$ & 1 & unitless & & A11 & Van Winkle et al. 1997 \\
\hline$K S_{s p w n}$ & 0.8 & unitless & & A11 & Van Winkle et al. 1997 \\
\hline$K S_{s p w n}$ & 0.7 & unitless & & A11 & Van Winkle et al. 1997 \\
\hline \multicolumn{6}{|c|}{ Spawning } \\
\hline$E_{\text {egg }}$ & 45.72 & $\mathrm{~J} \cdot \mathrm{egg}^{-1}$ & Energy density of an individual egg & & USDA 2001 \\
\hline \multicolumn{6}{|c|}{ Movement } \\
\hline $\begin{array}{c}\alpha_{\text {HSIdis }}, \beta_{\text {HSIdis }}, \\
\delta_{\text {HSIdis }} \\
\alpha_{\text {connect }},\end{array}$ & $\begin{array}{c}65.252,111.03,63.3 \\
100.083,123.107\end{array}$ & unitless & Parameters of the discharge-habitat suitability relationship & A13a & Peters and Perham 2008 \\
\hline$\beta_{\text {connect }}, \delta_{\text {connect }}$ & 38.099 & unitless & Parameters in the discharge-connectivity relationship & $\mathrm{A} 13 \mathrm{~b}$ & Peters and Perham 2008 \\
\hline$t_{\text {move }}$ & 2.5 & $h r s \cdot d^{-1}$ & Time that shovelnose sturgeon are active & $\mathrm{A} 13 \mathrm{c}$ & Calibration \\
\hline$P_{m i g}$ & 0.004 & unitless & Probability of immigration from the system & & Calibration \\
\hline \multicolumn{6}{|c|}{ Mortality } \\
\hline $\begin{array}{c}Z_{\text {egg }} \\
Z_{y o l k s a c}\end{array}$ & $\begin{array}{c}0.99 \\
0.438\end{array}$ & $\begin{array}{l}\text { year }^{-1} \\
\text { year }^{-1}\end{array}$ & $\begin{array}{l}\text { Instantaneous rate of predation mortality (eggs) } \\
\text { Instantaneous rate of predation mortality (yolk-sac larvae) }\end{array}$ & $\begin{array}{l}\mathrm{A} 14 \\
\mathrm{~A} 14\end{array}$ & $\begin{array}{l}\text { Calibration } \\
\text { Calibration }\end{array}$ \\
\hline$Z_{\text {angl }}$ & 0.43 & year $^{-1}$ & $\begin{array}{l}\text { Instantaneous rate of angling mortality } \\
\text { Coefficient of the size-dependent predation mortality function }\end{array}$ & A14 & Peters and Perham 2008 \\
\hline$\alpha_{\text {Zpred }}$ & 0.4 & unitless & $\begin{array}{c}\text { (feeding larvae and YAO) } \\
\text { Exponent of the size-dependent predation mortality function }\end{array}$ & A14a & Calibration \\
\hline$\beta_{\text {Zpred }}$ & $0.676,0.08$ & unitless & (feeding larvae and YAO) & A14a & Calibration \\
\hline$\alpha_{T r b}, \beta_{T r b}, \delta_{T r b}$ & $1.2102,298.61,178.88$ & unitless & Parameters in the turbidity function & A14b & Gadomski and Parsley 2005 \\
\hline$\alpha_{S}$ & 0.1 & unitless & Intercept of the starvation mortality function & A15 & Calibration \\
\hline$\beta_{S}$ & 0.4 & unitless & Coefficient of the starvation mortality function & A15 & Calibration \\
\hline
\end{tabular}




\section{References}

Bevelhimer, M. S. 2002. A bioenergetics model for white sturgeon Acipenser transmontanus: assessing differences in growth and reproduction among Snake River reaches. Journal of Applied Ichthyology 18:550-556.

Gadomski, D. M., and M. J. Parsley. 2005. Effects of turbidity, light level, and cover on predation of white sturgeon larvae by prickly sculpins. Transactions of the American Fisheries Society 134:369-374.

Hanson, P. C., T. B. Johnson, D. E. Schindler, and J. F. Kitchell. 1997. Fish bioenergetics 3.0. University of Wisconsin Sea Grant Institute, Madison, WI.

Lantry, B. F., and D. J. Stewart. 1993. Ecological energetics of rainbow smelt in the Laurentian Great Lakes: an interlake comparison. Transactions of the American Fisheries Society 122:951-976.

Peters, E. J., and J. E. Parham. 2008. Ecology and management of sturgeon in the lower Platte River, Nebraska. Nebraska Technical Series.

Rose, K. A., J. A. Tyler, R. C. Chambers, G. Klein-MacPhee, and D. J. Danila. 1996. Simulating winter flounder population dynamics using coupled individual-based young-of-the-year and age-structured adult models. Canadian Journal of Fisheries and Aquatic Sciences 53:1071-1091.

Shuman, D. A., J. E. Parham, and E. J. Peters. 2007. Stock characteristics of shovelnose sturgeon in the lower Platte River, Nebraska. Journal of Applied Ichthyology 23:484-488.

Tripp, S. J., Q. E. Phelps, R. E. Colombo, J. E. Garvey, B. M. Burr, D. P. Herzog, and R. A. Hrabik. 2009. Maturation and reproduction of shovelnose sturgeon in the middle Mississippi River. North American Journal of Fisheries Management 29:730738.

USDA. 2001. USDA (U.S. Department of Agriculture, Agricultural Research) Nutrient Database for Standard Reference. http://www.nal.usda.gov/fnic/foodcomp.

Van Winkle, W., K. A. Rose, B. J. Shuter, H. I. Jager, and B. D. Holcomb. 1997. Effects of climatic temperature change on growth, survival, and reproduction of rainbow trout: predictions from a simulation model. Canadian Journal of Fisheries and Aquatic Sciences 54:2526-2542.

Wang, Y., R. Buodington, and S. Doroshov. 1987. Influence of temperature on yolk utilization by the white sturgeon, Acipenser transmontanus. Journal of Fish Biology 30:263-271.

Wang, Y. L., F. P. Binkowski, and S. I. Doroshov. 1985. Effect of temperature on early development of white and lake sturgeon, Acipenser transmontanus and A. fulvescens. Environmental Biology of Fishes 14:43-50. 


\section{Appendix C. Derivation of environmental input data.}

Time-series inputs of temperature, discharge, depth, width, and turbidity derived from the LPR field survey data by the United States Geological Survey (USGS) National Water Information System (http://waterdata.usgs.gov/nwis). Discharge data are measured at five gauging stations along the river; Duncan (USGS station\# 06774000), North Bend (\#06796000), Leshara (\#06796500), Ashland (\#06801000), and Louisville (\#06805500). In the model environment, discharge rates from these stations are assigned to grid cell \# 1, 50, 76, 128, and 162, respectively. The discharge rates of grid cells between these stations are then estimated by linear interpolation.

Because of limited data availability (e.g., no measurement during winters), we used a wave function to estimate daily and depth average temperature $\left(T_{\text {ave }}\right)$ as

$$
T_{\text {ave }}=\alpha_{T}-\beta_{T} \cos \left(0.0172 t_{\mathrm{DOY}}\right)-\gamma_{T} \sin \left(0.0172 t_{\mathrm{DOY}}\right)
$$

where $\alpha_{T}, \beta_{T}$, and $\gamma_{T}$ are parameters that vary among simulation years (Appendix D).

Depth, width, and turbidity of each grid cell were estimated by empirically derived nonlinear functions of daily discharge rate for each simulation year as

$$
\begin{gathered}
\text { Width }=\gamma_{\text {wid }}+\alpha_{\text {wid }}\left(1-\beta_{\text {wid }}{ }^{\text {disc }}\right) \\
\text { Depth }=\gamma_{\text {dep }}+\alpha_{d e p}\left(1-\mathrm{e}^{-\beta_{\text {dep }} d i s c}\right) \\
\text { Turb }=\gamma_{t u r b}+\alpha_{t u r b}\left(1-\mathrm{e}^{-\beta_{\text {turb }}{ }^{d i s c}}\right)
\end{gathered}
$$

where $\alpha_{w i d}, \beta_{\text {wid }}, \gamma_{\text {wid }}, \alpha_{d e p}, \beta_{d e p}, \gamma_{\text {dep }}, \alpha_{t u r b}, \beta_{t u r b}$, and $\gamma_{\text {turb }}$ are parameters that vary among simulation years (Appendix D), and disci is daily discharge rate.

Photoperiod is calculated using a function of longitude and day of year (Forsythe et al. 1995) as

$$
\begin{gathered}
D L=24-2\left[(12 / \pi) \arccos \left(\tan (\pi L a t / 180) \times \tan \left(\delta_{D L}\right)\right]\right. \\
\delta_{D L}=(23.45 / 180) \pi \cos [(2 \pi / 365) \times(173-D O Y)]
\end{gathered}
$$

where Lat is latitude and $D O Y$ is day of year.

\section{References}

Forsythe, W. C., E. J. Rykiel Jr, R. S. Stahl, H.-i. Wu, and R. M. Schoolfield. 1995. A model comparison for daylength as a function of latitude and day of year. Ecological Modelling 80:87-9. 
Appendix D. Sources and values of the environment model parameters.

\begin{tabular}{|c|c|c|c|c|c|}
\hline Parameter & Value & Units & Description & Equation & Source \\
\hline \multicolumn{6}{|c|}{ Temperature } \\
\hline$\alpha_{T}$ & $\begin{array}{l}\text { varies among years }(1995- \\
\text { 2011) } \\
\text { varies among years }(1995-\end{array}$ & unitless & Parameter in the mean daily water temperature function & $\mathrm{C} 1$ & Estimated from field data \\
\hline$\beta_{T}$ & $\begin{array}{l}\text { 2011) } \\
\text { varies among years (1995- }\end{array}$ & unitless & Parameter in the mean daily water temperature function & $\mathrm{C} 1$ & Estimated from field data \\
\hline$\gamma_{T}$ & 2011) & unitless & Parameter in the mean daily water temperature function & $\mathrm{C} 1$ & Estimated from field data \\
\hline \multicolumn{6}{|c|}{ River width } \\
\hline$\alpha_{\text {wid }}$ & $\begin{array}{c}252.31,244.49,328.60 \\
229.24,194.70 \\
0.9041,0.9923,0.9943\end{array}$ & unitless & $\begin{array}{l}\text { Parameter in the discharge-river width relationship }(1,50,78, \\
128 \text {, and } 162 \text {, respectively) } \\
\text { Parameter in the discharge-river width relationship }(1,50,78,\end{array}$ & $\mathrm{C} 2$ & Estimated from field data \\
\hline$\gamma_{\text {wid }}$ & $183.44,155.29,168.75,167.56$ & unitless & 128, and 162 respectively) & $\mathrm{C} 2$ & Estimated from field data \\
\hline \multicolumn{6}{|c|}{ River depth } \\
\hline$\alpha_{d e p}$ & $\begin{array}{l}0.9663,0.7820,0.9909 \\
4.4333,0.7484\end{array}$ & unitless & $\begin{array}{l}\text { Parameter in the discharge-river depth relationship } 1,50,78 \text {, } \\
\qquad 128 \text {, and } 162 \text {, respectively) }\end{array}$ & $\mathrm{C} 3$ & Estimated from field data \\
\hline$\beta_{\text {dep }}$ & $\begin{array}{l}1.2562,1.6957,1.3614 \\
1.7589,2.10063\end{array}$ & unitless & $\begin{array}{l}\text { Parameter in the discharge-river depth relationship }(1,50,78, \\
\qquad 128 \text {, and } 162 \text {, respectively) }\end{array}$ & $\mathrm{C} 3$ & Estimated from field data \\
\hline$\gamma_{\mathrm{dep}}$ & $\begin{array}{l}0.0089,0.0022,0.0024 \\
0.0015,0.0012\end{array}$ & unitless & $\begin{array}{l}\text { Parameter in the discharge-river depth relationship }(1,50,78, \\
128 \text {, and } 162 \text {, respectively) }\end{array}$ & $\mathrm{C} 3$ & Estimated from field data \\
\hline \multicolumn{6}{|c|}{ Turbidity } \\
\hline$\alpha_{\text {turb }}$ & $-68.8031,12.3288$ & unitless & $\begin{array}{l}\text { Mean and SD of parameter in the discharge-turbidity } \\
\text { relationship } \\
\text { Mean and SD of parameter in the discharge-turbidity }\end{array}$ & $\mathrm{C} 4$ & Estimated from field data \\
\hline$\beta_{\text {turb }}$ & $990.8303,59.4367$ & unitless & $\begin{array}{l}\text { relationship } \\
\text { Mean and SD of parameter in the discharge-turbidity }\end{array}$ & $\mathrm{C} 4$ & Estimated from field data \\
\hline$\gamma_{\text {turb }}$ & $0.001,0.0001$ & unitless & relationship & $\mathrm{C} 4$ & Estimated from field data \\
\hline \multicolumn{6}{|c|}{ Photoperiod } \\
\hline Lat & 41 & $\circ$ & Latitude of the Lower Platte River & $\mathrm{C} 5$ & \\
\hline \multicolumn{6}{|c|}{ Drift prey production } \\
\hline$B_{\text {preyinit }}$ & 18.8 & $\mathrm{~g} \cdot \mathrm{m}^{-2}$ & Initial drift prey biomass & A1a & Whiles and Goldowitz 2005 \\
\hline$G R_{\text {prey }}$ & 0.175 & $g \cdot d^{-1}$ & Growth rate of drift prey & A1a & Rashleigh and Grossman 2005 \\
\hline Var preyprod & 0.25 & unitless & Variance in drift prey growth & A1a & Rashleigh and Grossman 2005 \\
\hline$B_{\text {maxprey }}$ & 117.6 & $\mathrm{~g} \cdot \mathrm{m}^{-2}$ & Maximum drift prey biomass & A1a & Whiles and Goldowitz 2005 \\
\hline$\alpha q_{\text {prod }}$ & 1.01 & unitless & Parameters of the discharge-habitat quality relationship & A1a & Estimated \\
\hline$\beta q_{\text {prod }}$ & 0.603 & unitless & Parameters of the discharge-habitat quality relationship & A1a & Estimated \\
\hline$\gamma q_{\text {prod }}$ & 0.249 & unitless & Parameters of the discharge-habitat quality relationship & A1a & Estimated \\
\hline$m_{\text {prod }}$ & 0.0007 & $\mathrm{~d}^{-1}$ & Net migration rate & A1a & Rashleigh and Grossman 2005 \\
\hline
\end{tabular}




\section{References}

Rashleigh, B., and G. D. Grossman. 2005. An individual-based simulation model for mottled sculpin (Cottus bairdi) in a southern Appalachian stream. Ecological Modelling 187:247-258.

Whiles, M. R., and B. S. Goldowitz. 2005. Macroinvertebrate communities in central Platte River wetlands: patterns across a hydrologic gradient. Wetlands 25:462-472. 